\title{
Probing $\mathrm{Al}$ distribution in $\mathrm{LiCo}_{0.96} \mathrm{Al}_{0.04} \mathrm{O}_{2}$ materials using ${ }^{7} \mathrm{Li},{ }^{27} \mathrm{Al}$ and ${ }^{59} \mathrm{Co}$ MAS NMR combined with synchrotron X-ray diffraction
}

\author{
Marie Duffiet $^{1,2}$, Maxime Blangero ${ }^{2}$, Pierre Etienne Cabelguen ${ }^{3}$, Kyeong Se Song ${ }^{2}$, \\ François Fauth ${ }^{4}$, Claude Delmas ${ }^{1}$, Dany Carlier ${ }^{1, *}$ \\ ${ }^{1}$ CNRS, Univ. Bordeaux, Bordeaux INP, ICMCB UPR 9048, F-33600 Pessac, France \\ ${ }^{2}$ Umicore, Materials Research and Development, Cheonan-Si, Chungnam-Do 330-200, Korea \\ ${ }^{3}$ Umicore Rechargeable battery materials, 31 rue du marais, Brussels BE-1000, Belgium \\ ${ }^{4}$ CELLS - ALBA synchrotron, Cerdanyola del Vallès, E-08290 Barcelona, Spain \\ *Corresponding author: dany.carlier@icmcb.cnrs.fr
}

\begin{abstract}
We prepared Al-doped LCO (LCA) powders with low Al content (4\%) with a controlled $\mathrm{Li} /(\mathrm{Co}+\mathrm{Al})$ stoichiometry by a solid state reaction using $\mathrm{Li}_{2} \mathrm{CO}_{3}$ and two types of $\mathrm{Co} / \mathrm{Al}$ precursors : simply mixed $\left(\mathrm{Co}_{3} \mathrm{O}_{4}\right.$ and $\left.\mathrm{Al}_{2} \mathrm{O}_{3}\right)$ or heat treated $\left(\mathrm{Co}_{3} \mathrm{O}_{4}\right.$ and $\left.\mathrm{Al}_{2} \mathrm{O}_{3}\right)$. These samples were thereby used to propose a reliable protocol aiming to discuss the homogeneity of the Al doping for $\mathrm{LiCo}_{1}$ ${ }_{y} \mathrm{Al}_{\mathrm{y}} \mathrm{O}_{2}$ (LCA) prepared with low $\mathrm{Al}$ content by evidencing the distribution of $\mathrm{Al}$ within the powders, which clearly affect the electrochemical profiles of associated LCA//Li cells. For all samples we initially also characterized by ${ }^{7} \mathrm{Li}$ MAS NMR the Li/(Co+Al) stoichiometry, to discard the possible effect of $\mathrm{Li}$ excess in the samples. Synchrotron XRD combined with ${ }^{27} \mathrm{Al}$ and ${ }^{59} \mathrm{Co}$ MAS NMR provided then a deep understanding of the doping homogeneity at the powder or particle scale. We showed that doping the $\mathrm{Co}_{3} \mathrm{O}_{4}$ spinel precursor by reacting it with $\mathrm{Al}_{2} \mathrm{O}_{3}$ may be
\end{abstract}


avoided, as it most likely leads to an inhomogeneous mixture of $\mathrm{Co}_{3} \mathrm{O}_{4}$ and $\mathrm{Co}_{3-\mathrm{z}} \mathrm{Al}_{\mathrm{z}} \mathrm{O}_{4}$ as precursor, eventually reflecting in the final $\mathrm{LiCo}_{0.96} \mathrm{Al}_{0.04} \mathrm{O}_{2}$ powder, which shows a nonhomogeneous $\mathrm{Al}$ distribution. We believe that such a detailed characterization should be the first step towards a deeper understanding of the real beneficial effect(s) of Al doping on the high voltage performance of LCO.

\section{Introduction}

While lithium cobaltite $\mathrm{LiCoO}_{2}$ (LCO) has been used as positive electrode material in Li-ion batteries for almost 30 years, only $60 \%$ of its theoretical capacity is used in commercial cells. Attempts to reversibly de-intercalate more Li from LCO result in poor cycling performances due to strong degradation of the conventional carbonate-based electrolytes ${ }^{1,2}$, structural instabilities $^{3-7}$ and cobalt dissolution ${ }^{8}$ observed at high voltage $\left(\mathrm{V}>4.3 v s . \mathrm{Li}^{+} / \mathrm{Li}\right)$. The substitution of some $\mathrm{Co}^{3+}$ ions with various dopants ${ }^{9-12} \mathrm{M}(\mathrm{M}=\mathrm{Mg}, \mathrm{Ti}, \mathrm{Zr}, \mathrm{Cr} .$.$) or more recently co-dopants { }^{13-15}\left(\mathrm{M}, \mathrm{M}^{\prime}\right)$ like (Mn, Mg), (Mg, Ti) or ( $\mathrm{La}, \mathrm{Al})$, has been reported to be an effective strategy to improve the cycle life of LCO at high voltage.

Aluminum ions as dopants were among the first considered, by the means of theoretical calculations from Ceder's group ${ }^{16}$, followed by experimental work from Jang et. $a l^{17}$ and other groups ${ }^{18-20}$. The choice for aluminum was motivated by: i) its low cost and non-toxicity, ii) a similar radius for $\mathrm{Al}^{3+}$ compared to $\mathrm{Co}^{3+}(0.535 \AA$ vs. $0.545 \AA)$ facilitating the substitution of the latter and preserving the initial structure leading to the full solid solution $\mathrm{LiCo}_{1-\mathrm{y}} \mathrm{Al}_{\mathrm{y}} \mathrm{O}_{2}$. $\mathrm{Al}$-doped LCO has been reported to experience: i) less volume changes ${ }^{17,18}$, ii) a decreased cobalt dissolution $^{18}$, and iii) the suppression of spinel disorder onto the surface of the particles as 
compared to $\mathrm{LCO}^{21}$, even though accelerate capacity fading was also demonstrated ${ }^{16,22}$. Although Al-doped LCO has been proposed several years ago as positive electrode material, the effect of Al doping on the phase transitions observed for LCO at high voltage and the impact of the $\mathrm{Al}$ distribution homogeneity in the material on the cycling performances are still unclear. Here, the challenge is to properly characterize the $\mathrm{Al}$ distribution for a low $\mathrm{Al}$ content (lower than 5\%) which will be one of the requirements to make Al-doped LCO a suitable candidate as positive electrode in Li-ion cells. This would be done using the high angular resolution of synchrotron XRD and solid state ${ }^{27} \mathrm{Al}$ and ${ }^{59} \mathrm{Co}$ MAS NMR. In order to address only the problem of the role of the $\mathrm{Al}$ distribution, one has to study samples with a proper control of the initial Li/M stoichiometry. Indeed, Levasseur et al. previously showed ${ }^{23-25}$ that $\mathrm{Li}$ excess during the synthesis of LCO powders leads to the formation of the so-called "overlithiated" $\mathrm{Li}_{1+\mathrm{t}} \mathrm{Co}_{1-t} \mathrm{O}_{2-\mathrm{t}}$ compounds, whose Li presence in Co sites associated to close-by oxygen vacancies not only changes the electrochemical signature but also significantly increases the capacity losses during the $1^{\text {st }}$ cycle. More recently, we also demonstrated that the phase transitions occurring at high voltage for LCO are also impacted by the initial Li/Co stoichiometry ${ }^{7}$. Thus, a parasitic effect of Li excess in Al-doped LCO with non-controlled Li stoichiometry may have, so far, led to incorrect conclusions. ${ }^{7}$ Li MAS NMR will be used here in order to ensure the Li/M stoichiometry of the studied compounds.

In literature, Al-doped materials are often synthesized through liquid media, featuring coprecipitation routes ${ }^{17,18,22,26-28}$, usually leading to homogeneous $\mathrm{Co}^{3+} / \mathrm{Al}^{3+}$. For industrial point of view, however, it is interesting to develop further solid state synthesis routes for the preparation of doped LCO, even though achieving a proper Al distribution may be more challenging. Samples studied here were prepared in rather large quantities $(\sim 200 \mathrm{~g})$ using solid state route with $\mathrm{Co}_{3} \mathrm{O}_{4}$ and $\mathrm{Al}_{2} \mathrm{O}_{3}$ as precursors with or without a heat treatment before the addition of lithium carbonate. 
Recently, the interdiffusion of $\mathrm{Co}$ and $\mathrm{Al}$ the interface of $\mathrm{LCO}$ and $\mathrm{Al}_{2} \mathrm{O}_{3}$ pellets using various temperature were studied we the aim to optimize the synthesis of $\mathrm{Al}_{2} \mathrm{O}_{3}$-coated $\mathrm{LCO}^{29,30}$. Here, we aim to discuss the homogeneity of $\mathrm{Al}$ distribution in Li-stoichiometric $\mathrm{LiCo}_{0.96} \mathrm{Al}_{0.04} \mathrm{O}_{2}$ phases prepared by solid state from two different precursors compared with a sample prepared via a liquid media. Their electrochemical properties are finally discussed in relation with the Al distribution.

\section{Experimental}

Sample preparation (A schematic figure summarizing all steps of the synthesis can be found in Supplemental Information-Figure S1):

Precursors: A 2 kg-blend containing $\mathrm{Co}_{3} \mathrm{O}_{4}$ (Umicore) and $\mathrm{Al}_{2} \mathrm{O}_{3}$ (Umicore) in a $\mathrm{Co} / \mathrm{Al}$ ratio of $0.96 / 0.04$ was initially prepared. After homogenizing the mixture for 1 hour at $1000 \mathrm{rpm}$ in a stainless steel container, it was split into two batches. The first batch (now called Precursor 1) was directly used to prepare P1-LCA. Note that a heat treatment of Precursor 1 at moderate temperature $\left(60{ }^{\circ} \mathrm{C}\right.$ ) did not lead to any reaction between $\mathrm{Co}_{3} \mathrm{O}_{4}$ and $\mathrm{Al}_{2} \mathrm{O}_{3}$ (in good agreement

with previous studies ${ }^{31-33}$ ). In the meantime, a heat treatment at $1000{ }^{\circ} \mathrm{C}$ for 10 hours under air flow was applied to the second batch. The fired mixture, now referred to as Precursor 2, was accordingly used to prepare P2-LCA.

LCA samples: Two LiCo0.96 $\mathrm{Al}_{0.04} \mathrm{O}_{2}$ (LCA) powders samples called "P1-LCA" and "P2-LCA" were both prepared by solid state synthesis of homogenized mixtures of $\mathrm{Li}_{2} \mathrm{CO}_{3}$ (Umicore) and a Co- and Al- based oxide precursors (P1 or P2, respectively). The mixtures to form the final LCA samples were prepared in rather large amounts $(220 \mathrm{~g})$ in the ratio $\mathrm{Li} /(\mathrm{Co}+\mathrm{Al})=0.99$ and homogenized for 4 hours with $\mathrm{Al}_{2} \mathrm{O}_{3}$ balls in a plastic container. Both were simultaneously 
heat treated in the same furnace for $12 \mathrm{~h}$ under air flow at $\mathrm{T}=980{ }^{\circ} \mathrm{C}$, followed by a second annealing at $\mathrm{T}=980{ }^{\circ} \mathrm{C}$ for $10 \mathrm{~h}$ under air. A final post-treatment step using a grinder was mandatory to pulverize the synthesized powder blocks. Additionally, the as-prepared powders were sieved (40 $\mu \mathrm{m}$ mesh).

For comparison purposes, additional reference samples were prepared. Non Al-doped stoichiometric (st-LCO) and overlithiated $\mathrm{LiCoO}_{2}$ (overl-LCO) were obtained from solid state synthesis of $\mathrm{Co}_{3} \mathrm{O}_{4}$ and $\mathrm{Li}_{2} \mathrm{CO}_{3}$ at $\mathrm{T}=980{ }^{\circ} \mathrm{C}$ for 10 hours under air flow, with respective $\mathrm{Li} / \mathrm{Co}$ ratios of 0.99 and 1.05. A 4\%-Al doped LCO called "Rf-LCA" was prepared by a citrate coprecipitation route, following the experimental protocol detailed in a previous article from Dahéron et. al. ${ }^{28} \mathrm{~A}$ solution of $\mathrm{Li}_{2} \mathrm{CO}_{3}, \mathrm{Al}\left(\mathrm{NO}_{3}\right)_{3} .9 \mathrm{H}_{2} \mathrm{O}$ and $\mathrm{CoCO}_{3}$ in citric acid $0.1 \mathrm{~mol} / \mathrm{L}$ was heated for 3 hours at $\mathrm{T}=80^{\circ} \mathrm{C}$. After ammonia was added to the solution to reach a $\mathrm{pH}$ value of 7 , the solvent was evaporated using a rotary evaporator. The solid residue was subsequently heat treated 3 times at: i) $\mathrm{T}=200{ }^{\circ} \mathrm{C}$ for $10 \mathrm{~h}$ under air, ii) $\mathrm{T}=450{ }^{\circ} \mathrm{C}$ for $12 \mathrm{~h}$ under $\mathrm{O}_{2}$ and iii) $\mathrm{T}=900{ }^{\circ} \mathrm{C}$ for $12 \mathrm{~h}$ under $\mathrm{O}_{2}$. The residue was systematically grinded and pelletized between each heat treatment, and sieved after the last one $\left(40-\mu \mathrm{m}\right.$ mesh). To confirm our interpretation of the ${ }^{59}$ Co MAS NMR spectra a 10\% Al doped LCO sample has also been prepared using the same citrate-route.

\section{Samples characterization.}

Powder X-ray diffraction (XRD) patterns were collected on a PANalitycal X'pert PRO MPD diffractometer in Bragg-Brentano $\theta-\theta$ geometry equipped with a Fe filter, a spinner and $\mathrm{X}^{\prime}$ Celerator 
multi-strip detector. Each measurement was made within an angular range of $2 \theta=10-120^{\circ}$ and lasted for 15 hours, at $0.016^{\circ}$ intervals. The Co-Ka radiation was generated at $35 \mathrm{kV}$ and $30 \mathrm{~mA}$ $\left(\lambda\left(\mathrm{K}_{\alpha 1}\right)=1.789 \AA ; \lambda\left(\mathrm{K}_{\alpha 2}\right)=1.793 \AA\right)$. Additional high angular resolution synchrotron powder $\mathrm{X}-$ ray diffraction (SXRD) experiments were performed on the BL04-MSPD beamline of the ALBA synchrotron (Cerdanyola del Vallès, Spain). All powders were packed in $0.5 \mathrm{~mm}$ diameter capillaries. The patterns were recorded in Debye-Scherrer geometry with a wavelength of $\lambda=$ $0.825 \AA$. The typical $2 \Theta$ angular range was $0-70^{\circ}$ with $0.006^{\circ}$ angular step and 3-minute-long accumulation time. Regarding the high crystallinity of the $\mathrm{Co}_{3} \mathrm{O}_{4}$ and $\mathrm{LCO}$ compounds, the angular step of the MYTHEN detector used for this study was not sufficiently low to properly refine the XRD patterns using the Rietveld method. Therefore, only Le Bail refinements were carried out.

${ }^{7} \mathrm{Li}$ MAS NMR spectra were recorded on a Bruker 300 Advance spectrometer at $116.66 \mathrm{MHz}$ (7.05 T magnet), with a standard $2.5 \mathrm{~mm}$ Bruker MAS probe. A Hahn echo sequence $\left[\mathrm{t}_{\pi / 2}-\tau 1-\mathrm{t}_{\pi}-\tau 2\right]$ synchronized with one period of rotor rotation was used for a $30 \mathrm{kHz}$ spinning frequency. The $90^{\circ}$ pulse duration was equal to $\mathrm{t}_{\pi / 2}=2.0 \mu \mathrm{s}$ and determined using a $\mathrm{LiCl} 1 \mathrm{M}$ solution. A recycle time of $\mathrm{D}_{0}=40 \mathrm{~s}$ was used for st-LCO and LCA samples, whereas a shorter $\mathrm{D}_{0}=2 \mathrm{~s}$ was enough for the overl-LCO sample, to avoid $\mathrm{T}_{1}$ saturation effects.

Single pulse ${ }^{27} \mathrm{Al}$ MAS NMR spectra were recorded on a Bruker $500 \mathrm{MHz}$ spectrometer at 130.33 MHz (11.7 T magnet) using a standard Bruker $2.5 \mathrm{~mm}$ MAS probe with a $30 \mathrm{kHz}$ typical spinning frequency. The spectral width was set to $0.5 \mathrm{MHz}$ and the recycle time to $\mathrm{D}_{0}=5 \mathrm{~s}$, long enough to avoid $\mathrm{T}_{1}$ saturation effects. $\mathrm{As}{ }^{27} \mathrm{Al}$ is a strong quadrupolar nucleus with $\mathrm{I}=5 / 2$, a short pulse length of $1.1 \mu$ s corresponding to a $\pi / 12$ pulse determined using an aqueous $1 \mathrm{M} \mathrm{Al}\left(\mathrm{NO}_{3}\right)_{3}$ solution was employed. In these conditions, all of the $-1 / 2 \rightarrow+1 / 2$ central transitions are equally excited regardless of the magnitude of the nuclear quadrupole coupling constants and one can 
extract quantitative data. The external reference was a $1 \mathrm{M} \mathrm{Al}\left(\mathrm{NO}_{3}\right)_{3}$ aqueous solution. For the samples containing only $4 \%$ of Al, overnight experiments (10240 scans) were carried out to ensure a good signal/noise ratio. No baseline subtraction was done in the figures presented here.

${ }^{59}$ Co MAS NMR spectra were recorded on a Bruker $500 \mathrm{MHz}$ spectrometer at $120.35 \mathrm{MHz}$ (11.7 T magnet) using a standard Bruker $2.5 \mathrm{~mm}$ MAS probe with a $30 \mathrm{kHz}$ typical spinning frequency. The spectral width was set to $0.5 \mathrm{MHz}$ and the recycle time to $\mathrm{D}_{0}=1 \mathrm{~s}$. Single $\pi / 16$ pulse and rotor-synchronized Hahn echo sequences were used. A comparison of the spectra for one sample is given in Figure S2. Even if not quantitative, only spectra recorded with a Hahn echo sequence $\left[\mathrm{t}_{\pi / 2}-\tau 1-\mathrm{t}_{\pi}-\tau 2\right]$ with $\mathrm{t}_{\pi / 2}=2.5 \mu$ s are presented here. This sequence facilitates the phasing of all the signals and ensures the observation of possible very wide signals which are lost during the receiver dead time. The external reference was a $1 \mathrm{M} \mathrm{K}_{3} \mathrm{Co}(\mathrm{CN})_{6}$ aqueous solution.

Electrochemical tests were performed in coin cells, using pure lithium as counter-electrode and $1 \mathrm{M} \mathrm{LiPF}_{6}$ in EC:DEC:DMC as electrolyte. LCA:C:PVDF electrodes (90:5:5\% $\left.\%_{\mathrm{wt}}\right)$ were prepared from a slurry using N-methyl-pyrrolidone (NMP) as solvent casted onto a $30 \mu \mathrm{m}$-thick-aluminum foil. After evaporating the NMP for 2 hours at $\mathrm{T}=80{ }^{\circ} \mathrm{C}, \Phi 15 \mathrm{~mm}$ electrodes were cut in the obtained film with typical active material loading of $10 \mathrm{mg} / \mathrm{cm}^{2}$. The electrodes were then dried overnight under vacuum at $\mathrm{T}=120^{\circ} \mathrm{C}$ and stored in an argon-filled glovebox, whose cell assembling was carried out.

Scanning electron micrographs were taken using a Hitachi Model S-4500 microscope after metallizing the powders with gold.

Inductively Coupled Plasma (ICP) measurements were carried out on Agilent ICP-720ES equipment after sample dissolution in concentrated $\mathrm{HCl}$ solution under heating. 


\section{Results and discussion}

\section{A. Precursors characterization}

The major difference between the two LCA samples prepared by solid state chemistry lies in the used Co/Al-based precursor: homogenized mixture of $\mathrm{Co}_{3} \mathrm{O}_{4}$ and $\mathrm{Al}_{2} \mathrm{O}_{3}$ (Precursor 1) or same mixture heat treated at $1000^{\circ} \mathrm{C}$ heat (Precursor 2). Therefore, a special attention to the Co/Al-based precursor is then given in the following to establish the relevance of the heat treatment of $\mathrm{Co}_{3} \mathrm{O}_{4}$ and $\mathrm{Al}_{2} \mathrm{O}_{3}$ with $\mathrm{Co} / \mathrm{Al}=0.96 / 0.04$ prior to the addition of lithium carbonate, using SEM, SXRD, and ${ }^{27} \mathrm{Al}$ MAS NMR.

SEM micrographs of Precursors are given in Figure 1. A population of $<10 \mathrm{~nm}$-sized particles corresponding to $\mathrm{Al}_{2} \mathrm{O}_{3}$ can be clearly distinguished on top of $\mathrm{Co}_{3} \mathrm{O}_{4}$ particles whose average size is several hundreds of nanometers for Precursor 1 (Fig. 1a). On the other hand, only one type of bigger particles ( $\mu \mathrm{m}$-size) is observed for Precursor 2 (Fig. 1b). This suggests that the reaction between $\mathrm{Al}_{2} \mathrm{O}_{3}$ and $\mathrm{Co}_{3} \mathrm{O}_{4}$ has occurred at $1000^{\circ} \mathrm{C}$, jointly with crystalline growth usually observed at high temperatures.

SXRD patterns for Precursors 1 and 2 are plotted in Figure 2. A reference pattern from $\mathrm{Co}_{3} \mathrm{O}_{4}$ is also provided for better comparison. Recording of XRD patterns using synchrotron radiation was motivated by the expected noticeable gain in detection limit that may reveal information regarding impurities or alumina itself. No matter the $\mathrm{Al}$ content $z$, the evolution of the $a_{c u b}$. cell parameter for $\mathrm{Co}_{3-\mathrm{z}} \mathrm{Al}_{2} \mathrm{O}_{4}$ is expected to be negligible due to comparable ionic radiuses of $\mathrm{Co}^{3+}(0.545 \AA)$ and $\mathrm{Al}^{3+}(0.535 \AA)$. Values of $8.084 \AA$ for $\mathrm{Co}_{3} \mathrm{O}_{4}, 8.086 \AA$ for $\mathrm{Co}_{2} \mathrm{AlO}_{4}$ and $8.104 \AA$ for $\mathrm{CoAl}_{2} \mathrm{O}_{4}$ are typically reported for $\mathrm{a}_{\text {cub. }}{ }^{32}$. Thus, within the angular resolution limits of the 
SXRD experiment, not surprisingly the diffraction peaks for $\mathrm{Co}_{3} \mathrm{O}_{4}$, Precursor 1 and Precursor 2 are found at identical $2 \Theta$ positions. All peaks can be indexed in the $F d 3 m$ space group with a cell parameter $a_{c u b}$ equal to 8.084(2) Å. In particular, no signal ascribed to the presence of crystalline alumina could be detected for either Precursor 1 or Precursor 2 in Figure 2, even though alumina is clearly seen in Figure 1 for the former. The $\mathrm{Al}_{2} \mathrm{O}_{3}$ particles present in $\mathrm{P} 1$ thus, must be really disordered with very small particles size $(<10 \mathrm{~nm})$. After such heat treatment used to form Precursor 2, the formation of mix- $\mathrm{Co}_{3-\mathrm{z}} \mathrm{Al}_{\mathrm{z}} \mathrm{O}_{4}$ phase is expected ${ }^{31,32}$. The diffraction peaks of Precursor 1 are found to be slightly broader than those of Precursor $2\left(\mathrm{~T}=1000{ }^{\circ} \mathrm{C}\right)$. No additional information regarding the $\mathrm{Al}$ distribution itself within the precursors could be gathered from SXRD.

Figure 3 shows the ${ }^{27} \mathrm{Al}$ MAS NMR spectra recorded for the different precursors used for the LCA materials synthesis. The $\mathrm{Al}_{2} \mathrm{O}_{3}$ precursor exhibits a spectrum typical of the $\gamma$-form of $\mathrm{Al}_{2} \mathrm{O}_{3}$ with two broad signals localized around 65 and 9 ppm, assigned respectively to $\mathrm{Al}$ in tetrahedral and octahedral environments ${ }^{34-36}$. The strong asymmetrical broadening of the signals toward lower shifts originates from distributions of quadrupolar couplings typically observed in disordered compounds. The $\mathrm{Co}_{3} \mathrm{O}_{4}$ mixed with $\mathrm{Al}_{2} \mathrm{O}_{3}$ (Precursor 1) still logically exhibits the same ${ }^{27} \mathrm{Al}$ MAS NMR signature as $\gamma-\mathrm{Al}_{2} \mathrm{O}_{3}$, therefore un-reacted. On the contrary, as no signal is observed in the same recording conditions after a heat treatment of these precursors at $1000{ }^{\circ} \mathrm{C}$ for 10h (Precursor 2), we conclude that $\mathrm{Al}_{2} \mathrm{O}_{3}$ did react with $\mathrm{Co}_{3} \mathrm{O}_{4}$ in good agreement with the SEM observations and with the literature (a minimum temperature of $800{ }^{\circ} \mathrm{C}$ was reported ${ }^{31-33}$ for the reaction of $\mathrm{Co}_{3} \mathrm{O}_{4}$ and $\gamma-\mathrm{Al}_{2} \mathrm{O}_{3}$ to form $\mathrm{Co}_{3-\mathrm{z}} \mathrm{Al}_{2} \mathrm{O}_{4}$ ). The absence of signal for $\mathrm{Al}$ in doped $\mathrm{Co}_{3} \mathrm{O}_{4}$ is most likely due to strong hyperfine coupling with paramagnetic cobalt species either leading to very fast relaxation times or to such a broadening that they cannot be resolved in our conditions. 
Similar effect was also reported for $\mathrm{CoAl}_{2} \mathrm{O}_{4}$ and for other paramagnetic materials ${ }^{37,38}$. Therefore, no further information about the distribution of Al within Precursor 2 could be gathered here. Nonetheless, at this point, SEM, SXRD and ${ }^{27} \mathrm{Al}$ MAS NMR helped proving the different chemical natures of Precursor 1 or 2, the latter containing an Al-doped spinel phase as opposed to the former.

\section{B. $\mathrm{LiC00.96} \mathrm{Al}_{0.04} \mathrm{O}_{2}$ characterization}

\section{General characterizations}

As aluminum is found in different environments for Precursor 1 or 2, (i. e. included in $\mathrm{Co}_{3} \mathrm{O}_{4}$ matrix or not), two final associated LCA materials were prepared after addition of $\mathrm{Li}_{2} \mathrm{CO}_{3}$. The goal of this study was to investigate the homogeneity of the aluminum distribution within the LCA phases and evaluate its influence on the electrochemical behavior, without any interference due to the presence of $\mathrm{Li}$ excess. Therefore, we strictly prepared the samples using $\mathrm{Li} /(\mathrm{Co}+\mathrm{Al})=0.99$ in the precursors mixture in order to get real stoichiometric samples LCA with $\mathrm{Li} /(\mathrm{Co}+\mathrm{Al})=1.00$ with possibly remaining spinel and $\mathrm{Al}_{2} \mathrm{O}_{3}$.

Table I gives the final $\mathrm{Al} /(\mathrm{Co}+\mathrm{Al})$ and $\mathrm{Li} /(\mathrm{Co}+\mathrm{Al})$ ratios measured with $\mathrm{ICP}$ for $\mathrm{P} 1$ - and P2-LCA. Both samples exhibit $\mathrm{Al} /(\mathrm{Co}+\mathrm{Al})$ values close to the expected $4 \%$ one $(\mathrm{Al} /(\mathrm{Co}+\mathrm{Al})=0.038$ for $\mathrm{P} 1-\mathrm{LCA}$ and $\mathrm{Al} /(\mathrm{Co}+\mathrm{Al})=0.040$ for $\mathrm{P} 2-\mathrm{LCA})$. Accurate control of the final $\mathrm{Li} /(\mathrm{Co}+\mathrm{Al})$ was achieved, as revealed by the measured values always found slightly below $1.00(\mathrm{Li} /(\mathrm{Co}+\mathrm{Al})=0.995$ for $\mathrm{P} 1-\mathrm{LCA}$, and $\mathrm{Li} /(\mathrm{Co}+\mathrm{Al})=0.992$ for P2-LCA $)$. Laboratory XRD and ${ }^{7} \mathrm{Li}$ MAS NMR were respectively used to check the possible presence of unreacted $\mathrm{Co}_{3} \mathrm{O}_{4}$ (expected if $\mathrm{Li} /(\mathrm{Al}+\mathrm{Co})<1)$ and the stoichiometry of the LCA samples, as extra signals are expected if $\mathrm{Li} /(\mathrm{Al}+\mathrm{Co})>1$. In Figure 4.a, all XRD patterns show the peaks associated to layered crystallized 
(O3) structure indexed in the $R-3 m$ space group, similarly to the un-doped $\mathrm{LiCoO}_{2}$ we used as reference here (st-LCO). Two additional weak peaks are observed at $2 \Theta^{\circ}=36.5^{\circ}$ and $2 \Theta=43.1^{\circ}$ in all XRD patterns, indexed as the (220) and (311) in the $F d 3 m$ space group showing the presence of some remaining cobalt-based oxide precursors, as expected from the use of the $\mathrm{Li} /(\mathrm{Co}+\mathrm{Al})=0.99$ ratio in the precursors mixture. For the $\mathrm{O} 3 \mathrm{LCA}$ phases, a small overall peak broadening can be observed with the addition of aluminum in the samples. A slightly larger chex parameter is obtained from refinement of the XRD patterns for the $4 \%$ Al-doped samples (14.063(7) $\AA$ for P1-LCA and 14.065(8) $\AA$ for P2-LCA) compared to their undoped analogue st-LCO (14.047(1) A). Such change (0.13\%) is clearly highlighted in Figure 4.b by the shift observed for the (003) peak. The evolution of the $a_{h e x}$ parameter is expected to follow the reverse trend, even though with much less variation. The change trend of the cell parameters are here in good agreement with the observations already reported in the literature for LCA with larger aluminum content ${ }^{17,18,26,39}$. Figure 5 shows the recorded ${ }^{7} \mathrm{Li}$ MAS NMR spectra for P1- and P2-LCA. Both are plotted and compared to that of undoped $\mathrm{LiCoO}_{2}$ materials prepared without and with an excess of lithium carbonate designed as st-LCO (stoichiometric, $\mathrm{Li} / \mathrm{Co}=1.00$ ) and overl-LCO (overlithiated, $\mathrm{Li} / \mathrm{Co}=1.05$ ), respectively. As already reported, ${ }^{7} \mathrm{Li}$ MAS NMR is the key technique to probe the $\mathrm{Li} / \mathrm{Co}$ stoichiometry in those materials ${ }^{23,24}$; in st-LCO, $\mathrm{Li}$ is present in a single diamagnetic environment as all cobalt ions are in low spin state $\left(\mathrm{LS}^{-\mathrm{Co}^{3+}}\right)$, leading to a single signal located at $-0.4 \mathrm{ppm}$. On the other hand, several signals are observed for overl-LCO. Indeed, intermediate spin state paramagnetic (IS- $\mathrm{Co}^{3+}$ ) cobalt ions are formed due to the presence of $\mathrm{Li}$ in the Co site associated with an $\mathrm{O}$ vacancy ${ }^{24}$. Due to the Fermi contact interaction, adjacent Li can exhibit negative or positive shifted signals (out of the narrow chemical shifts range of ${ }^{7} \mathrm{Li}$ ), depending on its environment. The spectrum of overl-LCO does exhibit, therefore, in addition to the main signal at $-0.4 \mathrm{ppm}$, a large number of more shifted signals (Figure 5). Since the ${ }^{7} \mathrm{Li}$ MAS 
NMR spectra of the two 4\% Al-doped LCA samples do not exhibit those extra signals, this confirms that these materials are really Li-stoichiometric and do not contain any paramagnetic species. These results are therefore in good agreement with the previous $\mathrm{Li} /(\mathrm{Co}+\mathrm{Al})$ ratios measured by $\mathrm{ICP}$. Moreover, long $\mathrm{T}_{1}$ relaxation times, typical for diamagnetic materials, were determined (T1 5 s). Note that the ${ }^{7} \mathrm{Li}$ MAS signal of the two LCA samples is slightly broader than the one of st-LCO due to a distribution of $\mathrm{Li}$ environments versus $\mathrm{Co} / \mathrm{Al}$ in the materials (Figure $\mathrm{S} 3$ ).

\section{Homogeneity of Al-doping within P1- and P2-LCA}

To further investigate the homogeneity of Al distribution within P1- and P2-LCA (which could not be debated from laboratory XRD or ${ }^{7} \mathrm{Li}$ MAS NMR), SXRD patterns and ${ }^{27} \mathrm{Al}$ and ${ }^{59} \mathrm{Co}$ MAS NMR spectra were collected.

Figure 6.a gives a general view of the SXRD patterns for P1- and P2-LCA and first leads to the similar conclusions as laboratory $\mathrm{XRD}$, i.e. pure layered phases crystallizing in the $R-3 m$ space group were obtained, with small traces of spinel precursor impurity. Diffraction peaks for Al-doped samples are also found broader and at different $2 \Theta$ positions than those of undoped stLCO, as shown by the shifts of the (018) and (110) diffraction peaks (Figure 6.c and 6.d). This confirms the substitution of $\mathrm{Co}^{3+}$ with $\mathrm{Al}^{3+}$ in LCA samples which leads to a decrease of the $a_{\text {hex. }}$. parameter and an increase of the $c_{h e x}$ one. Those two diffraction lines have been chosen here to reflect the evolution of the $a_{\text {hex. }}$ and $c_{\text {hex. }}$ parameters. The evolution of the $c_{\text {hex }}$ parameter is predominating in the shift of the (018) peak. Note that Figure 6.c and 6.d were normalized to the overall peak area. An alternative plot of the data after normalization to the peak maxima is also provided in Figure S4. Moreover, strong additional peak asymmetries can clearly be observed for 
P1- and P2-LCA, while it does not exist for st-LCO. This asymmetry is found for any of the diffraction peaks collected within our $2 \Theta$ range, as shown by Figure 6.b; it varies with the (hkl) values of the diffraction lines. As shown by Gaudin et al. ${ }^{26}$ for the $\mathrm{Li}\left(\mathrm{Co}_{1-\mathrm{x}} \mathrm{Al} \mathrm{l}_{\mathrm{x}}\right) \mathrm{O}_{2}$ solid solution, the $c_{\text {hex. }}$ increases of $1 \%$ in the overall composition range $(0 \leq \mathrm{x} \leq 1)$ whereas the ahex. parameter decreases of $0.5 \%$. As shown in Figure 6.b, the asymmetry of the (101) lines is observed towards smaller $2 \theta$ angles for LCA samples, since the variation of $c_{\text {hex }}$ is predominating. On the other hand, as the (110) line is only affected by the ahex. parameter, the asymmetry is observed toward higher angles (Fig. 6.d). This asymmetry is further evidence of the presence of a distribution of Al concentration in the particles of the two LCA samples. Nevertheless, P2-LCA shows slightly more asymmetry than P1-LCA, suggesting that an even less homogeneous distribution of $\mathrm{Al}$ is achieved for P2-LCA. In Figure 6.d, the (110) peak for P2-LCA does also exhibit a shoulder centered at the (110) peak position of the undoped st-LCO, implying that domains without Al within P2-LCA do exist (their contribution better seen for this diffraction line). In Figure 7, the shape of the (110) and (018) diffraction lines of P1-LCA and P2-LCA is compared to the one of Rf-LCA sample prepared by precipitation route, known to yield a more homogenous doping ${ }^{26,27}$ as expected, Rf-LCA does exhibit symmetrical lines due to a homogeneous Al/Co cation mixing. Therefore, these SXRD results first suggest that i) in our solid state synthesis conditions, heterogeneous Al distribution was observed and ii) the final Al distribution is dependent on the Co- and Al-based oxide precursor type (with or without a $1000^{\circ} \mathrm{C}$ heat treatment).

${ }^{27} \mathrm{Al}$ MAS NMR was additionally used to locally probe the different Al environments distribution in the LCA materials at a local scale. Complete spectrum included spinning sidebands manifold can be found in Figure S4. A zoom on the central transitions is shown in Figure 8. As shown in Figure 8.a, the P2-LCA compound clearly exhibits seven signals. They can be assigned 
to the different $\mathrm{Al}$ environments versus second Co neighbors in the transition metal (TM) layer, as already reported by Gaudin et $\mathrm{al}^{26}$. The signal located around $\sim 62 \mathrm{ppm}$ is assigned to $\mathrm{Al}$ surrounded only by $\mathrm{LS}-\mathrm{Co}^{3+}$ ions as second neighbors denoted as $\mathrm{Al}-\left(\mathrm{Al}_{0} \mathrm{Co}_{6}\right)$. Note that this signal exhibits a clear second order quadrupolar lineshape could be fitted (see Figure S6) leading to $\delta_{\text {iso }}=64.7 \mathrm{ppm}$, $v_{\mathrm{Q}}=386 \mathrm{kHz}$ and $\eta=0.15$ as parameters. A value close to zero was indeed expected for the Al$\left(\mathrm{Al}_{0} \mathrm{Co}_{6}\right)$ local environment as it is expected to exhibit an axial symmetry if one considers only this first cationic coordination sphere. The set of other signals located equally spaced by 7-8 ppm, located at $\sim 55, \sim 48, \sim 40, \sim 33, \sim 26, \sim 18$ ppm are assigned to Al surrounded by $\mathrm{n} \mathrm{Al}^{3+}$ and $(6-\mathrm{n})$ $\mathrm{Co}^{3+}$ as second neighbors with $\mathrm{n}$ varying respectively from 0 to 6 , denoted $\mathrm{Al}-\left(\mathrm{Al}_{\mathrm{n}} \mathrm{Co} 6-\mathrm{n}\right)$. Those signals do not exhibit a clear second order lineshape anymore due to a distribution of possible local configurations for each $\mathrm{Al}-\left(\mathrm{Al}_{\mathrm{n}} \mathrm{Co}_{6-\mathrm{n}}\right)(0 \leq \mathrm{n} \leq 6)$ environment. Small signals located around 69 and $73 \mathrm{ppm}$ are assigned to the satellite transitions expected for the main signal arising from Al-( $\left.\mathrm{Al}_{0} \mathrm{Co}_{6}\right)$ environments. Satellites transitions of the other signals are probably overlapping their neighboring signal on the left, preventing a highly precise quantitative analysis. Nevertheless, we computed the probability $\mathrm{P}(\mathrm{y}, 6-\mathrm{n})$ for a composition with $\mathrm{y}=0.04$ and $(6-\mathrm{n})$ cobalt atoms $(0 \leq \mathrm{n} \leq$ 6) as second neighbors using a binomial law:

$$
P(y, 6-n)=C_{6}^{6-n} y^{n}(1-y)^{6-n}
$$

The resulting theoretical intensity distribution is schematically depicted by the yellow rectangles in Figure 8.b. For such a low Al-doping amount, negligible signal intensity is expected for Al$\left(\mathrm{Al}_{3} \mathrm{Co}_{3}\right)$ environments and for Al-richer ones $(\mathrm{n}>3)$. Therefore, the two LCA prepared by solidstate route do not exactly follow this trend, confirming inhomogeneity in the Al-distribution within the samples suspected from SXRD. We also compared these materials to the $4 \% \mathrm{Al}$-doped $\mathrm{LiCoO}_{2}$ material obtained from a citrate precursor route (Rf-LCA). Signals assigned to Al-rich environments are less intense for the latter than those of P1- and P2-LCA, and closely follows the 
intensity distribution theoretically expected. Therefore, this result confirms the high homogeneity of $\mathrm{Al}$ distribution for LCA prepared by the citrate route while infirming it for P1- and P2-LCA. Nevertheless, the departure from the ideal Al distribution is larger for P2-LCA than for P1-LCA in good agreement with the SXRD results.

${ }^{59}$ Co MAS NMR was reciprocally used to characterize the Co local environments in the materials. This is the first report of ${ }^{59} \mathrm{Co}$ MAS NMR study of Al-doped $\mathrm{LiCoO}_{2}$ samples. The complete spectrum of P2-LCA included spinning sidebands manifold can be found in Figure S5. Figure 9 shows the spectra recorded for P1- and P2-LCA compared with those of undoped stoichiometric $\mathrm{LiCoO}_{2}$ (st-LCO) and $4 \%$ doped via the citrate route (Rf-LCA). The MAS spectra are observed to break into spinning side bands and the resolution is good enough to evidence different signals. For st-LCO, a single resonance is observed at $14132 \mathrm{ppm}$ in agreement with Siegel et $a l .{ }^{40}$ and is assigned to the single octahedral LS-Co ${ }^{3+}$ site in the material. In the Al-doped samples, a set of other as broad signals are observed located at 14105, 14077, 14047, and 14021 $\mathrm{ppm}$, that we propose to respectively assigned to $\mathrm{Co}$ with various $2^{\text {nd }}\left(\mathrm{Al}_{n} \mathrm{Co}_{6} \mathrm{n}\right)$ neighbor environments as given in Figure 9. To confirm our signal assignment a 10\% Al-doped sample prepared by the citrate route was also studied by ${ }^{59} \mathrm{Co}$ and is presented in Figure S7 and S8. Despite broader signals observed for ${ }^{59} \mathrm{Co}$ MAS NMR, compared to ${ }^{27} \mathrm{Al}$ MAS NMR, distinct signals can be resolved. It appears that the most homogeneous samples exhibit weaker signal broadening (also seen in Figure S9). Indeed, the ${ }^{59}$ Co NMR chemical shift range is very large and the shift position is very sensitive to the local environments (distances, angles). For example, a signal was observed at $14115 \mathrm{ppm}$ in $\mathrm{O} 3-\mathrm{LiCoO}_{2}$ by Siegel et. al. ${ }^{40}$ and at $14722 \mathrm{ppm}$ in $\mathrm{O} 3-\mathrm{NaCoO}_{2}{ }^{41}$. An inhomogeneous $\mathrm{Al}$-doping in $\mathrm{LiCoO}_{2}$ thus generates a larger distribution of distances and angles around Co, leading to a broadening of the lines. 
SXRD, ${ }^{27} \mathrm{Al}$ and ${ }^{59} \mathrm{Co}$ MAS NMR all lead to the same conclusions. Our solid state synthesis route, even performed at relatively high temperature $\left(980^{\circ} \mathrm{C}\right)$ with either $\mathrm{Al}_{2} \mathrm{O}_{3}$ just mixed with $\mathrm{Co}_{3} \mathrm{O}_{4}$ or pre-heated at $1000^{\circ} \mathrm{C}$ as precursors, do not allow to prepare materials as homogeneous as the one prepared by the citrate route. A small gradient in composition is remaining in the P1- and P2-LCA samples. Nevertheless, the Al-doping of LCO was effective, since no signal of remaining $\mathrm{Al}_{2} \mathrm{O}_{3}$ is observed by ${ }^{27} \mathrm{Al}$ MAS NMR. While we initially thought that a pre-heat treatment of the $\mathrm{Al}$ and Co precursor might help to get homogeneous LCA samples, the opposite effect is actually observed: P2-LCA sample shows even more inhomogeneity of Al distribution than P1-LCA. These differences may arise from several causes. The formation of an inhomogeneous mixture of $\mathrm{Co}_{3} \mathrm{O}_{4}$ and $\mathrm{Co}_{3-\mathrm{z}} \mathrm{Al}_{\mathrm{z}} \mathrm{O}_{4}$ for Precursor 2 most likely leads to further heterogeneous $\mathrm{Al}$ distribution in the final P2-LCA phase. A preferential reaction between $\mathrm{Li}_{2} \mathrm{CO}_{3}$ and $\gamma-\mathrm{Al}_{2} \mathrm{O}_{3}$ may also be more favorable for the final Al distribution within P1-LCA. The particle size may also have played a role, as homogenization processes may be harder in the bigger particles of Precursor 2 as opposed to Precursor 1 during the formation of the associated LCA. Even though no clear conclusions on the precursors can be drawn, differences of $\mathrm{Al}$ distribution were still evidenced in both resulting LCA prepared from solid state synthesis thanks to the remarkable resolutions of SXRD and ${ }^{27} \mathrm{Al}$ MAS NMR.

\section{Electrochemical properties}

In the case of LCA powders, it seems reasonable to expect differences in the electrochemical profiles depending on the homogeneity of the Al distribution within the samples. Figure 10.a shows the $1^{\text {st }}$ cycle between 3.0 and 5.0 V at C/20, for coin cells with either st-LCO, P1-LCA, P2-LCA and Rf-LCA as positive electrodes. Discharge capacities and coulombic 
efficiency upon cycling are provided in Figure S11. Typical features characteristic of stoichiometric $\mathrm{LiCoO}_{2}$ (st-LCO) are clearly seen: i) the voltage jump corresponding to the $\mathrm{O} 3 \leftrightarrow$ O’3 monoclinic transition resulting from the formation of a Li-vacancy ordering at $\mathrm{x}=0.5$, (Figure 10.b and Figure 10.c): ii) the formation of the H1-3 phase around $\mathrm{x} \approx 0.17$, also revealed by a clear change of slope. The homogeneously Al-doped material Rf-LCA shows none of the above, as revealed by the overall slopping profile of the electrochemical curve. In particular, the O3 $\leftrightarrow$ O’3 monoclinic transition does not occur (Figure 10.c). Note that in the case of LCO, even a very little excess of $\mathrm{Li}$ found in the Co layers hinders the Li-vacancy ordering at $\mathrm{x}=0.5^{23,24}$. The occurrence of this transition is thus extremely sensible to the local perturbations within LCO-type materials. Since we controlled the initial $\mathrm{Li} /(\mathrm{Co}+\mathrm{Al})$ ratios in this study, only the presence of homogeneously distributed $\mathrm{Al}^{3+}$ in substitution of some $\mathrm{Co}^{3+}$ can explain the absence of the $\mathrm{O} 3 \leftrightarrow$ O’3 monoclinic transition. As a matter of fact, this could then be considered a first indirect tool to probe the dopants repartition within the doped LCO, when an accurate control of the $\mathrm{Li} /(\mathrm{Co}+\mathrm{Al})=1.00$ is achieved. For both $\mathrm{P} 1$ and $\mathrm{P} 2$-LCA, this $\mathrm{O} 3 \leftrightarrow \mathrm{O}$ '3 monoclinic transition occurs - as clearly evidenced by the small change of slope in the near $x=0.5$ region $($ Figure 10.b) and in the derivative $\mathrm{dx} / \mathrm{dV}$ curve (Figure 10.c). One can assume the coexistence of un-doped and Al doped domains due to the inhomogeneous distribution of $\mathrm{Al}$ ions to explain this behavior. This supports the previous conclusions obtained from SXRD and MAS NMR, i.e. that non homogeneous Al-doping was achieved by our solid state synthesis of LCA. It is though impossible to discriminate between P1- and P2-LCA respective performances after one cycle. Note that the polarization at high voltage, in discharge, is substantial for st-LCO compared to any other LCA. However, aluminum content itself cannot strictly explain this improvement: other parameters such as the difference in particle size observed in Figure $\mathbf{S 1 0}$ may also play a role. Nonetheless, this 
polarization makes it hard to discuss the existence, or not, of the H1-3 phase itself for LCA samples, especially for Rf-LCA. Weak changes of slope can still be observed in the high voltage region for all LCA, mainly evidenced during the discharge. Additionally, all Al-doped LCO show higher irreversible capacity vs undoped $\mathrm{LiCoO}_{2}$, following previous conclusions ${ }^{18}$.

\section{Conclusion}

In this paper, we prepared Al-doped LCO (LCA) powders with low Al content (4\%) with a controlled $\mathrm{Li} /(\mathrm{Co}+\mathrm{Al})$ stoichiometry by a solid state reaction using $\mathrm{Li}_{2} \mathrm{CO}_{3}$ and two type of $\mathrm{Co} / \mathrm{Al}$ precursors : mixed $\mathrm{Co}_{3} \mathrm{O}_{4}$ and $\mathrm{Al}_{2} \mathrm{O}_{3}$ or heat treated mixture. We established a reliable protocol to characterize the $\mathrm{Al}$ distribution within these LCA powders at different scales through the combined use of synchrotron XRD and ${ }^{27} \mathrm{Al} /{ }^{59} \mathrm{Co}$ MAS NMR. Our samples were compared to a phase prepared by a precipitation technique used as a reference sample. For all samples we initially also characterized by ${ }^{7} \mathrm{Li}$ MAS NMR the $\mathrm{Li} /(\mathrm{Co}+\mathrm{Al})$ stoichiometry, to discard the possible effect of $\mathrm{Li}$ excess in the samples. We showed that doping the $\mathrm{Co}_{3} \mathrm{O}_{4}$ spinel precursor by reacting it with $\mathrm{Al}_{2} \mathrm{O}_{3}$ may be avoided, as it most likely leads to an inhomogeneous mixture of $\mathrm{Co}_{3} \mathrm{O}_{4}$ and $\mathrm{Co}_{3-\mathrm{z}} \mathrm{Al}_{\mathrm{z}} \mathrm{O}_{4}$ as precursor, eventually reflecting in the final $\mathrm{LiCo}_{0.96} \mathrm{Al}_{0.04} \mathrm{O}_{2}$ powder, which shows a nonhomogeneous Al distribution. The comparison of the electrochemical performance of both LCA powders with a reference LCA sample prepared from co-precipitation route confirmed the inhomogeneity of $\mathrm{Al}$ doping, as typical features (such as the O3 $\leftrightarrow$ O’3 transition) obtained for undoped LCO were still distinguished for the former. Nonetheless, higher irreversible capacity was achieved at the outcome of the $1^{\text {st }}$ cycle for all LCA as compared to undoped LCO, confirming previous findings from Myung et. $a l^{18}$. As we carefully controlled the $\mathrm{Li} /(\mathrm{Co}+\mathrm{Al})$ stoichiometries of all LCA powders through ${ }^{7} \mathrm{Li}$ MAS NMR, the possible contribution of Li excess to the increase of capacity losses during the first cycle is discarded. 
Although both samples investigated in this section showed poor homogeneity of Al doping, this is

still a first encouraging step towards the preparation of homogenous Al-doped LCO materials by solid state route for high energy density LCA. Further studies will aim to improve the homogeneity of the samples using different temperature treatments and times and/or other precursors.

\section{Acknowledgments}

This work beneficiates from financial support from Umicore within the framework of Conventions Industrielles de Formation par la REcherche (CIFRE), handled by the Association Nationale Recherche Technologie (ANRT). We would like to thank them to this end. ALBA synchrotron is acknowledged for granting beamtime through proposal no 2017032163. We are also grateful to Laurent Gautier and Stéphane Levasseur (Umicore) for fruitful discussions. Mathieu Duttine and Cathy Denage are thanked for their technical support.

\section{Associated Contents/Supporting Information paragraph}

The Supporting Information is available free of charge on the ACS Publications website

Figure S1: Summarizing scheme of syntheses for P1- and P2-LCA. Figure S2: ${ }^{59}$ Co MAS NMR spectra $\mathrm{LiCo}_{0.96} \mathrm{Al}_{0.04} \mathrm{O}_{2}$ (ref-LCA) comparing Hahn Echo versus Single pulse sequences. Figure S3: Zoom on the ${ }^{7}$ Li MAS NMR spectra. Figure S4: Zoom on the $\left(\begin{array}{lll}0 & 1 & 8\end{array}\right)$ and $\left(\begin{array}{lll}1 & 1 & 0\end{array}\right)$ SXRD peaks normalized to the $\left(\begin{array}{lll}1 & 1 & 0\end{array}\right)$ peak maximum, as opposed to Figure 7.b and 7.c in which the data was normalized to the peak areas. Figure S5: Typical entire spectra recorded for a) ${ }^{27} \mathrm{Al}$ and b) ${ }^{59} \mathrm{Co}$ MAS NMR for the P2-LCA sample. Figure S6: Typical fit of a ${ }^{27}$ Al MAS NMR spectrum. Figure 
S7: ${ }^{59} \mathrm{Co}$ MAS NMR spectra of $4 \%$ and $10 \%$ Al-doped $\mathrm{LiCoO}_{2}$ samples prepared by the citrate route. Figure S8: ${ }^{7} \mathrm{Li},{ }^{27} \mathrm{Al}$ and ${ }^{59} \mathrm{Co} \mathrm{MAS}$ NMR spectra of $\mathrm{LiCo} 0.90 \mathrm{Al}_{0.10} \mathrm{O}_{2}$ sample prepared by the citrate route. Figure S9: ${ }^{59} \mathrm{Co}$ MAS NMR spectra recorded at $120.35 \mathrm{MHz}$ using a $30 \mathrm{kHz}$ spinning frequency of the P1-LCA and P2-LCA samples compared with the ones recorded for undoped st-LCO and a 4\% Al doped LCA samples prepared by a citrate route used as references. Figure S10: SEM micrographs of the powders of a) P1-LCA, b) P2-LCA and c) Rf-LCA. Figure S11: Discharge capacities and coulombic efficiency upon cycling of P1-LCA and P2-LCA at C/20 as positive electrode in Li//LCA cells, as compared to those of the undoped LCO (st-LCO). 


\section{References}

(1) Zhuang, Q.; Xu, J.; Fan, X.; Wei, G.; Dong, Q.; Jiang, Y.; Huang, L.; Sun, S. LiCoO 2 Electrode/Electrolyte Interface of Li-Ion Batteries Investigated by Electrochemical Impedance Spectroscopy. Sci. China Ser. B Chem. 2007, 50 (6), 776-783. https://doi.org/10.1007/s11426-007-0088-7.

(2) Würsig, A.; Buqa, H.; Holzapfel, M.; Krumeich, F.; Novák, P. Film Formation at Positive Electrodes in Lithium-Ion Batteries. Electrochem. Solid-State Lett. 2005, 8 (1), A34-A37. https://doi.org/10.1149/1.1836114.

(3) Ohzuku, T.; Ueda, A. Solid-State Redox Reactions of $\mathrm{LiCoO}_{2}(\mathrm{R} \overline{3 m})$ for 4 Volt Secondary Lithium Cells. J. Electrochem. Soc. 1994, $141 \quad$ (11), 2972-2977. https://doi.org/10.1149/1.2059267.

(4) Amatucci, G. G.; Tarascon, J. M.; Klein, L. C. $\mathrm{CoO}_{2}$, The End Member of the $\mathrm{Li}_{\mathrm{x}} \mathrm{CoO}_{2}$ Solid Solution. J. Electrochem. Soc. 1996, $143 \quad$ (3), 1114-1123. https://doi.org/10.1149/1.1836594.

(5) Chen, Z.; Lu, Z.; Dahn, J. R. Staging Phase Transitions in $\mathrm{Li}_{\mathrm{x}} \mathrm{CoO}_{2}$. J. Electrochem. Soc. 2002, 149 (12), A1604-A1609. https://doi.org/10.1149/1.1519850.

(6) Xia, H.; Lu, L.; Meng, Y. S.; Ceder, G. Phase Transitions and High-Voltage Electrochemical Behavior of $\mathrm{LiCoO}_{2}$ Thin Films Grown by Pulsed Laser Deposition. J. Electrochem. Soc. 2007, 154 (4), A337-A342. https://doi.org/10.1149/1.2509021.

(7) Duffiet, M.; Blangero, M.; Cabelguen, P.-E.; Delmas, C.; Carlier, D. Influence of the Initial Li/Co Ratio in $\mathrm{LiCoO}_{2}$ on the High-Voltage Phase-Transitions Mechanisms. J. Phys. Chem. Lett. 2018, 5334-5338. https://doi.org/10.1021/acs.jpclett.8b02252. 
(8) Amatucci, G. G.; Tarascon, J. M.; Klein, L. C. Cobalt Dissolution in $\mathrm{LiCoO}_{2}$-Based NonAqueous Rechargeable Batteries. Solid State Ion. 1996, 83 (1-2), 167-173. https://doi.org/10.1016/0167-2738(95)00231-6.

(9) Needham, S. A.; Wang, G. X.; Liu, H. K.; Drozd, V. A.; Liu, R. S. Synthesis and Electrochemical Performance of Doped $\mathrm{LiCoO}_{2}$ Materials. J. Power Sources 2007, 174 (2), 828-831. https://doi.org/10.1016/j.jpowsour.2007.06.228.

(10) Zou, M.; Yoshio, M.; Gopukumar, S.; Yamaki, J. Performance of LiM ${ }_{0.05} \mathrm{Co}_{0.95} \mathrm{O}_{2}$ Cathode Materials in Lithium Rechargeable Cells When Cycled up to 4.5 V. Chem. Mater. 2005, 17 (6), 1284-1286. https://doi.org/10.1021/cm048734o.

(11) Yu, J.; Han, Z.; Hu, X.; Zhan, H.; Zhou, Y.; Liu, X. The Investigation of Ti-Modified $\mathrm{LiCoO}_{2}$ Materials for Lithium Ion Battery. J. Power Sources 2014, 262, 136-139. https://doi.org/10.1016/j.jpowsour.2014.03.073.

(12) Prahasini, P.; Sivakumar, M.; Subadevi, R.; Wang, F. M. Synthesis and Characterization of $\mathrm{Cu}$ Doped $\mathrm{LiCoO}_{2}$ Cathode Material for Lithium Batteries Using Microwave Assisted SolGel Synthesis. Adv. Mater. Res. 2012, 584, 345-349. https://doi.org/10.4028/www.scientific.net/AMR.584.345.

(13) Liu, A.; Li, J.; Shunmugasundaram, R.; Dahn, J. R. Synthesis of Mg and Mn Doped $\mathrm{LiCoO}_{2}$ and Effects on High Voltage Cycling. J. Electrochem. Soc. 2017, 164 (7), A1655-A1664. https://doi.org/10.1149/2.1381707jes.

(14) Liu, Q.; Su, X.; Lei, D.; Qin, Y.; Wen, J.; Guo, F.; Wu, Y. A.; Rong, Y.; Kou, R.; Xiao, X.; et al. Approaching the Capacity Limit of Lithium Cobalt Oxide in Lithium Ion Batteries via Lanthanum and Aluminium Doping. Nat. Energy 2018. https://doi.org/10.1038/s41560-0180180-6. 
(15) Zhang, M.; Tan, M.; Zhao, H.; Liu, S.; Shu, X.; Hu, Y.; Liu, J.; Ran, Q.; Li, H.; Liu, X. Enhanced High-Voltage Cycling Stability and Rate Capability of Magnesium and Titanium Co-Doped Lithium Cobalt Oxides for Lithium-Ion Batteries. Appl. Surf. Sci. 2018, 458, 111118. https://doi.org/10.1016/j.apsusc.2018.07.091.

(16) Ceder, G.; Chiang, Y.-M.; Sadoway, D. R.; Aydinol, M. K.; Jang, Y.-I.; Huang, B. Identification of Cathode Materials for Lithium Batteries Guided by First-Principles Calculations. Nature 1998, 392 (6677), 694.

(17) Jang, Y.-I.; Huang, B.; Wang, H.; Sadoway, D. R.; Ceder, G.; Chiang, Y.-M.; Liu, H.; Tamura, H. LiAly $\mathrm{Co}_{1-\mathrm{y}} \mathrm{O}_{2}(\mathrm{R} 3 \mathrm{~m})$ Intercalation Cathode for Rechargeable Lithium Batteries. J. Electrochem. Soc. 1999, 146 (3), 862-868. https://doi.org/10.1149/1.1391693.

(18) Myung, S.-T.; Kumagai, N.; Komaba, S.; Chung, H.-T. Effects of Al Doping on the Microstructure of $\mathrm{LiCoO}_{2}$ Cathode Materials. Solid State Ion. 2001, 139 (1-2), 47-56. https://doi.org/10.1016/S0167-2738(00)00828-6.

(19) Lee, Y.; Woo, A. J.; Han, K.-S.; Ryu, K. S.; Sohn, D.; Kim, D.; Lee, H. Solid-State NMR Studies of Al-Doped and $\mathrm{Al}_{2} \mathrm{O}_{3}-$ Coated $\mathrm{LiCoO}_{2}$. Electrochimica Acta 2004, 50 (2-3), 491494. https://doi.org/10.1016/j.electacta.2004.02.063.

(20) Xu, H.-T.; Zhang, H.; Liu, L.; Feng, Y.; Wang, Y. Fabricating Hexagonal Al-Doped $\mathrm{LiCoO}_{2}$ Nanomeshes Based on Crystal-Mismatch Strategy for Ultrafast Lithium Storage. ACS Appl. Mater. Interfaces 2015, 7 (37), 20979-20986. https://doi.org/10.1021/acsami.5b06844.

(21) Wang, H.; Jang, Y.-I.; Huang, B.; Sadoway, D. R.; Chiang, Y.-M. Electron Microscopic Characterization of Electrochemically Cycled $\mathrm{LiCoO}_{2}$ and $\mathrm{Li}(\mathrm{Al}, \mathrm{Co}) \mathrm{O}_{2}$ Battery Cathodes. J. Power Sources 1999, 81-82, 594-598. https://doi.org/10.1016/S0378-7753(99)00108-1.

(22) Yoon, W.-S.; Lee, K.-K.; Kim, K.-B. Structural and Electrochemical Properties of LiAlyCo1y $\mathrm{O}_{2}$ Cathode for Li Rechargeable Batteries. J. Electrochem. Soc. 2000, 147 (6), 2023-2028. 
(23) Levasseur, S.; Menetrier, M.; Suard, E.; Delmas, C. Evidence for Structural Defects in NonStoichiometric HT-LiCoO 2 : Electrochemical, Electronic Properties and ${ }^{7} \mathrm{Li}$ NMR Studies. Solid State Ion. 2000, $128(1-4), 11-24$.

(24) Levasseur, S.; Ménétrier, M.; Shao-Horn, Y.; Gautier, L.; Audemer, A.; Demazeau, G.; Largeteau, A.; Delmas, C. Oxygen Vacancies and Intermediate Spin Trivalent Cobalt Ions in Lithium-Overstoichiometric $\mathrm{LiCoO}_{2}$. Chem. Mater. 2003, 15 (1), 348-354. https://doi.org/10.1021/cm021279g.

(25) Ménétrier, M.; Carlier, D.; Blangero, M.; Delmas, C. On "Really" Stoichiometric $\mathrm{LiCoO}_{2}$. $\begin{array}{llllll}\text { Electrochem. } & \text { Solid-State } & \text { Lett. } & \mathbf{2 0 0 8}, & 11 & \text { (11), }\end{array}$ https://doi.org/10.1149/1.2968953.

(26) Gaudin, E.; Taulelle, F.; Stoyanova, R.; Zhecheva, E.; Alcántara, R.; Lavela, P.; Tirado, J. L. Cobalt(III) Effect on ${ }^{27} \mathrm{Al}$ NMR Chemical Shifts in $\mathrm{LiAl}_{x} \mathrm{Co}_{1-x} \mathrm{O}_{2}$. J. Phys. Chem. B 2001, 105 (34), 8081-8087. https://doi.org/10.1021/jp0105948.

(27) Alcántara, R.; Lavela, P.; Relaño, P. L.; Tirado, J. L.; Zhecheva, E.; Stoyanova, R. X-Ray Diffraction, EPR, and ${ }^{6} \mathrm{Li}$ and ${ }^{27} \mathrm{Al}$ MAS NMR Study of $\mathrm{LiAlO}_{2}-\mathrm{LiCoO}_{2}$ Solid Solutions. Inorg. Chem. 1998, 37 (2), 264-269. https://doi.org/10.1021/ic9707220.

(28) Dahéron, L.; Dedryvère, R.; Martinez, H.; Flahaut, D.; Ménétrier, M.; Delmas, C.; Gonbeau, D. Possible Explanation for the Efficiency of Al-Based Coatings on $\mathrm{LiCoO}_{2}$ : Surface Properties of $\mathrm{LiCo}_{1-} \mathrm{Al}_{x} \mathrm{O}_{2}$ Solid Solution. Chem. Mater. 2009, 21 (23), 5607-5616. https://doi.org/10.1021/cm901972e.

(29) Han, B.; Paulauskas, T.; Key, B.; Peebles, C.; Park, J. S.; Klie, R. F.; Vaughey, J. T.; Dogan, F. Understanding the Role of Temperature and Cathode Composition on Interface and Bulk: Optimizing Aluminum Oxide Coatings for Li-Ion Cathodes. ACS Appl. Mater. Interfaces 2017, 9 (17), 14769-14778. https://doi.org/10.1021/acsami.7b00595. 
(30) Zhao, Y.; Li, J.; Dahn, J. R. Interdiffusion of Cations from Metal Oxide Surface Coatings into $\mathrm{LiCoO}_{2}$ During Sintering. Chem. Mater. 2017, 29 (12), 5239-5248. https://doi.org/10.1021/acs.chemmater.7b01219.

(31) Garcia Casado, P.; Rasines, I. The Series of Spinels $\mathrm{Co}_{3-\mathrm{s}} \mathrm{Al}_{\mathrm{s}} \mathrm{O}_{4}(0<\mathrm{s}<2)$ : Study of $\mathrm{Co}_{2} \mathrm{AlO}_{4}$. J. Solid State Chem. 1984, 52 (2), 187-190. https://doi.org/10.1016/00224596(84)90190-7.

(32) Zayat, M.; Levy, D. Blue $\mathrm{CoAl}_{2} \mathrm{O}_{4}$ Particles Prepared by the Sol-Gel and Citrate-Gel Methods. Chem. Mater. 2000, 12 (9), 2763-2769. https://doi.org/10.1021/cm001061z.

(33) Lee, G.-Y.; Ryu, K.-H.; Kim, H.-G.; Kim, Y.-Y. The Preparation of Blue $\mathrm{CoAl}_{2} \mathrm{O}_{4}$ Powders by the Malonate Method: The Effect of the Amount of Malonic Acid Used, the Formation Pathway of $\mathrm{CoAl}_{2} \mathrm{O}_{4}$ Crystallites and the Characteristics of the Prepared Powders. Bull. Korean Chem. Soc. 2009, 30 (2), 373-377.

(34) Smith, M. E. Application Of ${ }^{27} \mathrm{Al}$ NMR Techniques to Structure Determination in Solids. Appl. Magn. Reson. 1993, 4 (1-2), 1-64. https://doi.org/10.1007/BF03162555.

(35) O’Dell, L. A.; Savin, S. L. P.; Chadwick, A. V.; Smith, M. E. A ${ }^{27}$ Al MAS NMR Study of a Sol-Gel Produced Alumina: Identification of the NMR Parameters of the $\theta-\mathrm{Al}_{2} \mathrm{O}_{3}$ Transition Alumina Phase. Solid State Nucl. Magn. Reson. 2007, 31 (4), 169-173. https://doi.org/10.1016/j.ssnmr.2007.05.002.

(36) Samain, L.; Jaworski, A.; Edén, M.; Ladd, D. M.; Seo, D.-K.; Javier Garcia-Garcia, F.; Häussermann, U. Structural Analysis of Highly Porous $\gamma-\mathrm{Al}_{2} \mathrm{O}_{3}$. J. Solid State Chem. 2014, 217, 1-8. https://doi.org/10.1016/j.jssc.2014.05.004.

(37) Gaudon, M.; Apheceixborde, A.; Ménétrier, M.; Le Nestour, A.; Demourgues, A. Synthesis Temperature Effect on the Structural Features and Optical Absorption of $\mathrm{Zn}_{1-x} \mathrm{Co}_{x} \mathrm{Al}_{2} \mathrm{O}_{4}$ Oxides. Inorg. Chem. 2009, 48 (19), 9085-9091. https://doi.org/10.1021/ic900482v. 
(38) Kim, J.; Ilott, A. J.; Middlemiss, D. S.; Chernova, N. A.; Pinney, N.; Morgan, D.; Grey, C. P. ${ }^{2} \mathrm{H}$ and ${ }^{27} \mathrm{Al}$ Solid-State NMR Study of the Local Environments in Al-Doped 2-Line Ferrihydrite, Goethite, and Lepidocrocite. Chem. Mater. 2015, 27 (11), 3966-3978. https://doi.org/10.1021/acs.chemmater.5b00856.

(39) Takahashi, Y.; Kijima, N.; Akimoto, J. Single-Crystal Synthesis and Structure Refinement of the $\mathrm{LiCoO}_{2}-\mathrm{LiAlO}_{2}$ Solid-Solution Compounds: $\mathrm{LiAl}_{0.32} \mathrm{Co}_{0.68} \mathrm{O}_{2}$ and $\mathrm{LiAl}_{0.71} \mathrm{Co}_{0.29} \mathrm{O}_{2}$. J . Solid State Chem. 2005, 178 (12), 3667-3671. https://doi.org/10.1016/j.jssc.2005.09.016.

(40) Siegel, R.; Hirschinger, J.; Carlier, D.; Matar, S.; Ménétrier, M.; Delmas, C. ${ }^{59} \mathrm{Co}$ and ${ }^{6,7} \mathrm{Li}$ MAS NMR in Polytypes $\mathrm{O} 2$ and $\mathrm{O} 3$ of $\mathrm{LiCoO}_{2}$. J. Phys. Chem. B 2001, 105 (19), 41664174. https://doi.org/10.1021/jp003832s.

(41) Siegel, R.; Hirschinger, J.; Carlier, D.; Ménétrier, M.; Delmas, C. ${ }^{59} \mathrm{Co},{ }^{23} \mathrm{Na}$ NMR and Electric Field Gradient Calculations in the Layered Cobalt Oxides $\mathrm{NaCoO}_{2}$ and $\mathrm{HCoO}_{2}$. Solid State Nucl. Magn. Reson. 2003, 23 (4), 243-262. https://doi.org/10.1016/S09262040(03)00017-1. 

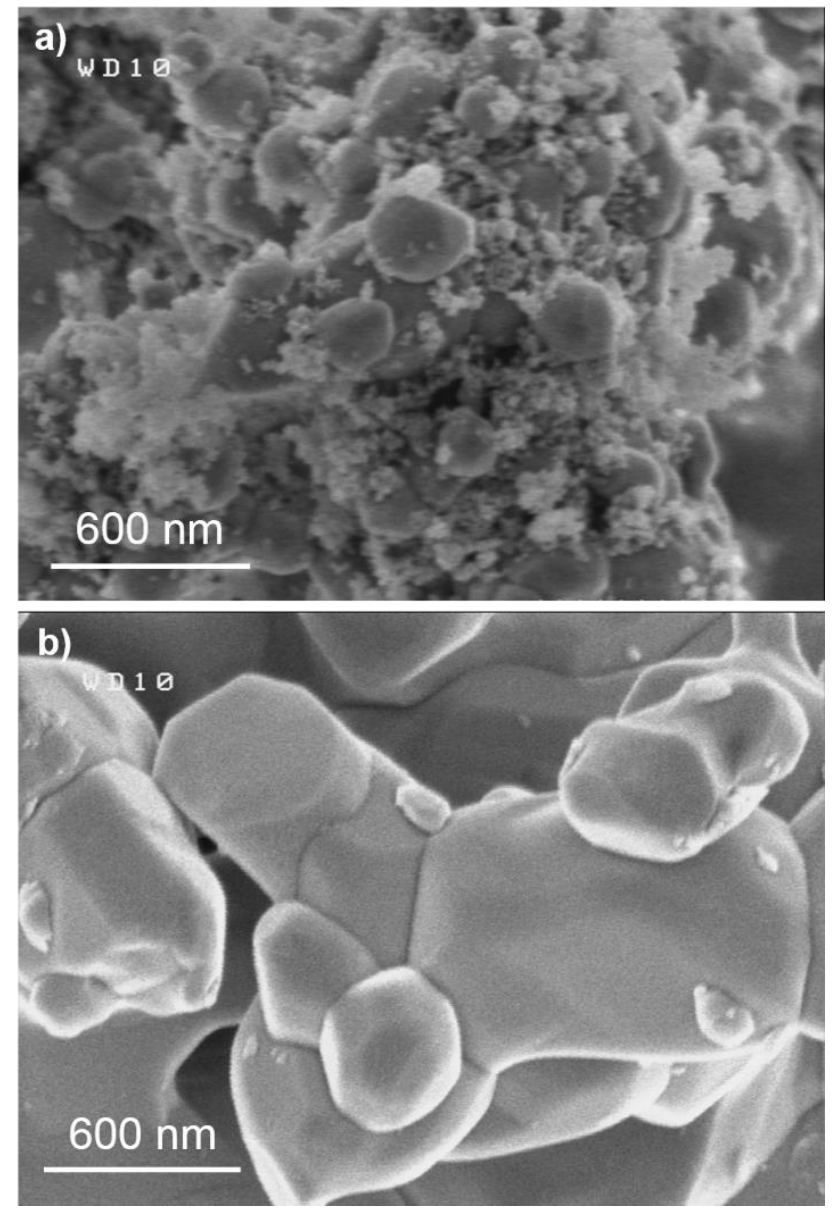

Figure 1. SEM micrographs of the powders of a) Precursor $1\left(\mathrm{Co}_{3} \mathrm{O}_{4}+\mathrm{Al}_{2} \mathrm{O}_{3}\right)$ and b) Precursor $2\left(\mathrm{Co}_{3} \mathrm{O}_{4}+\mathrm{Al}_{2} \mathrm{O}_{3}\right.$, heat treated at $1000^{\circ} \mathrm{C}$ for $10 \mathrm{~h}$ under air). 
a)
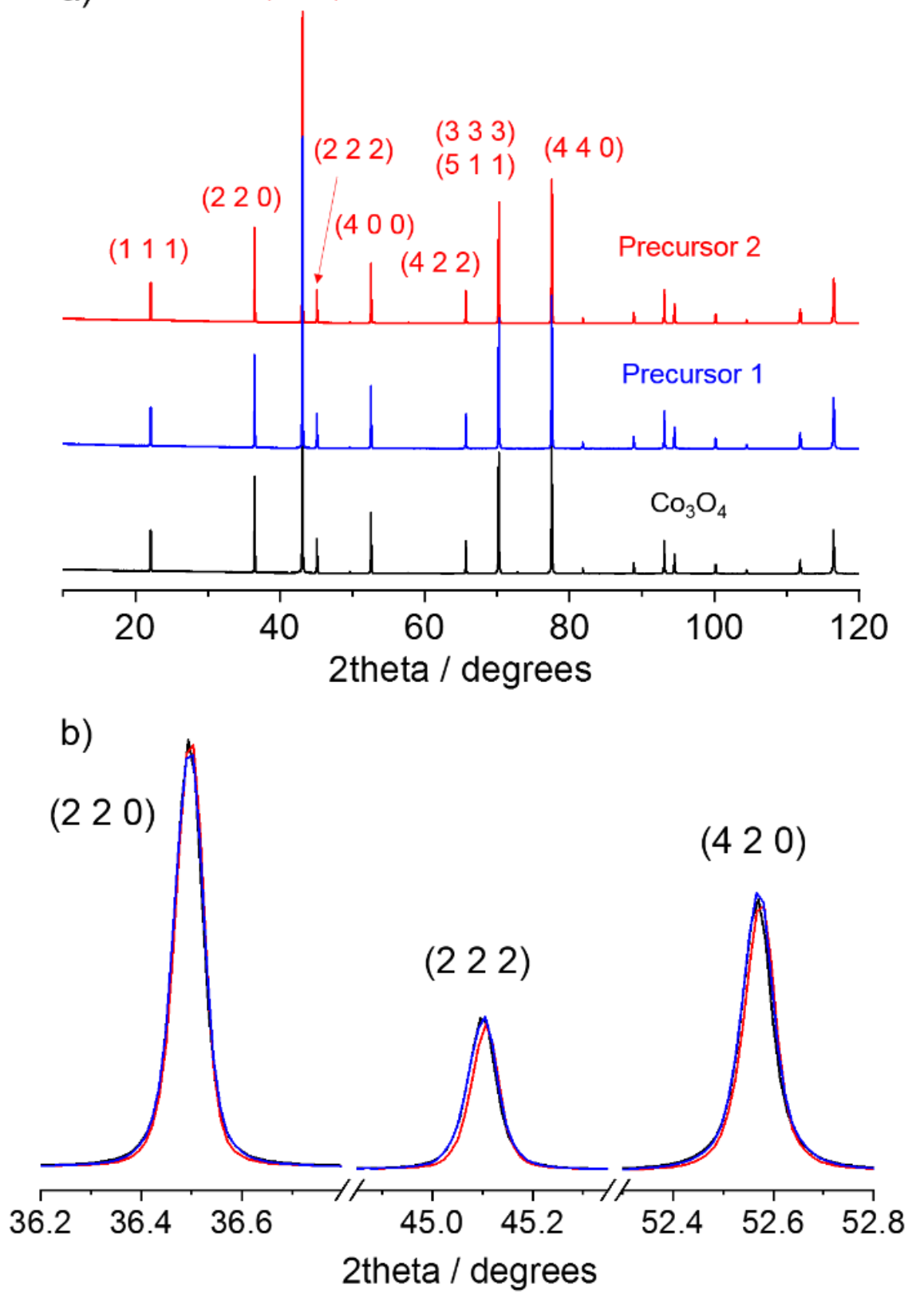

Figure 2. a) Synchrotron X-ray diffraction (SXRD) patterns obtained for a non-doped $\mathrm{Co}_{3} \mathrm{O}_{4}$ (black), as compared to the mixtures of $\mathrm{Co}_{3} \mathrm{O}_{4}+\mathrm{Al}_{2} \mathrm{O}_{3}$ (Precursor 1, in blue) or heat treated at $\mathrm{T}=1000^{\circ} \mathrm{C}$ (Precursor 2, in red). All patterns were collected for $\lambda=0.826 \AA$, but are converted here to $\lambda($ Сока1 $)=1.790 \AA$ for better comparison with all XRD patterns showed throughout the article. Miller indexes are specified for the most intense peaks. A zoom focusing on (2 20 ), (2 2 2) and (4 2 0) peaks is provided in b). 


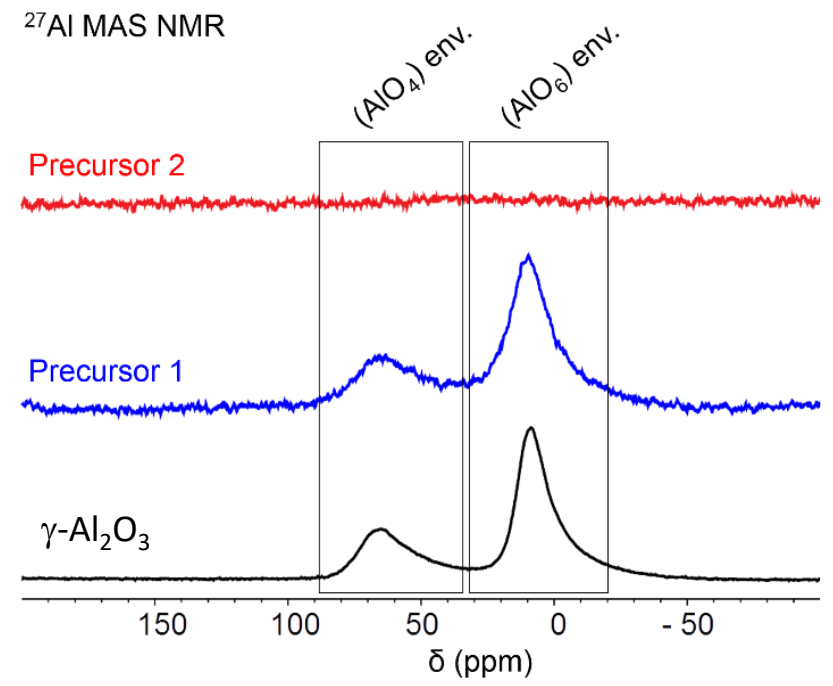

Figure 3. ${ }^{27} \mathrm{Al}$ MAS NMR spectra recorded at $130.33 \mathrm{MHz}$ using a $30 \mathrm{kHz}$ spinning frequency for Precursor $1,\left(\mathrm{Co}_{3} \mathrm{O}_{4}+\mathrm{Al}_{2} \mathrm{O}_{3}\right)$ in blue) and Precursor $2\left(\mathrm{Co}_{3} \mathrm{O}_{4}+\mathrm{Al}_{2} \mathrm{O}_{3}\right.$, heat treated at $\mathrm{T}=1000^{\circ} \mathrm{C}$ ) (in red), as compared to the spectra of pure $\gamma$-alumina (in black).

\begin{tabular}{ccc} 
Sample & $\mathrm{Li} /(\mathrm{Co}+\mathrm{Al})$ & $\mathrm{Al} /(\mathrm{Co}+\mathrm{Al})$ \\
\hline P1-LCA & $0.995(2)$ & $0.038(2)$ \\
P2-LCA & $0.992(2)$ & $0.040(2)$
\end{tabular}

Table I: Measured ICP ratios for the two final LCA powders. 

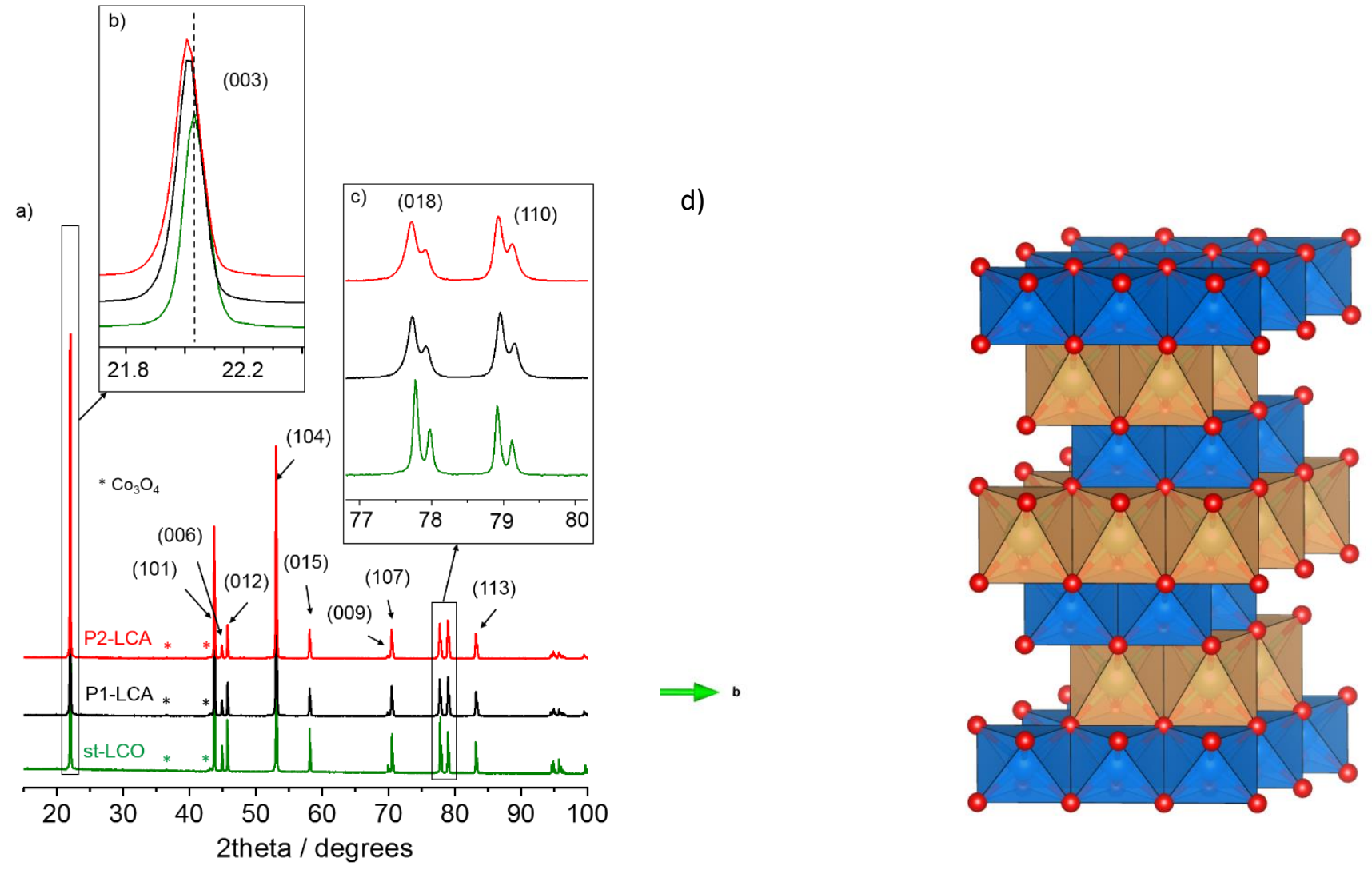

Figure 4. a) X-ray diffraction (XRD) data recorded for P1- and P2-LCA as compared to undoped LCO (st-LCO). These patterns were collected using a laboratory diffractometer

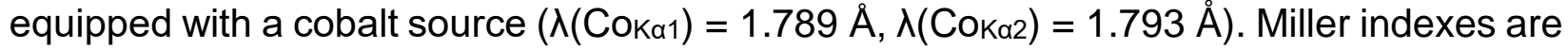
specified for all the peaks visible for $2 \Theta<90^{\circ}$. A zoom on the (003) diffraction peak is given in b), while (018) and (110) peaks are presented in c) and d) Representation of the O3 structure of the LCA phases. 

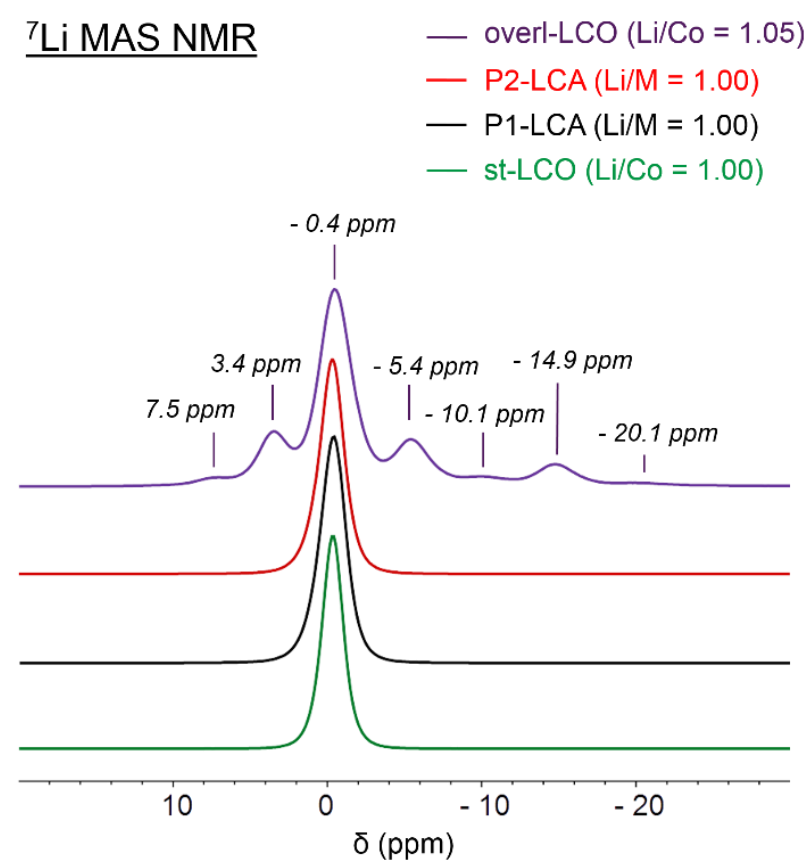

Figure 5. ${ }^{7} \mathrm{Li}$ MAS NMR spectra recorded at $116.66 \mathrm{MHz}$ using a $30 \mathrm{kHz}$ spinning frequency of the P1-LCA and P2-LCA samples compared with the ones of undoped LCO samples prepared in the stoichiometric conditions $(\mathrm{Li} / \mathrm{Co}=1.00$, st-LCO) or with an excess of $\mathrm{Li}$-carbonate $(\mathrm{Li} / \mathrm{Co}=1.05$, overl-LCO) used as references. 


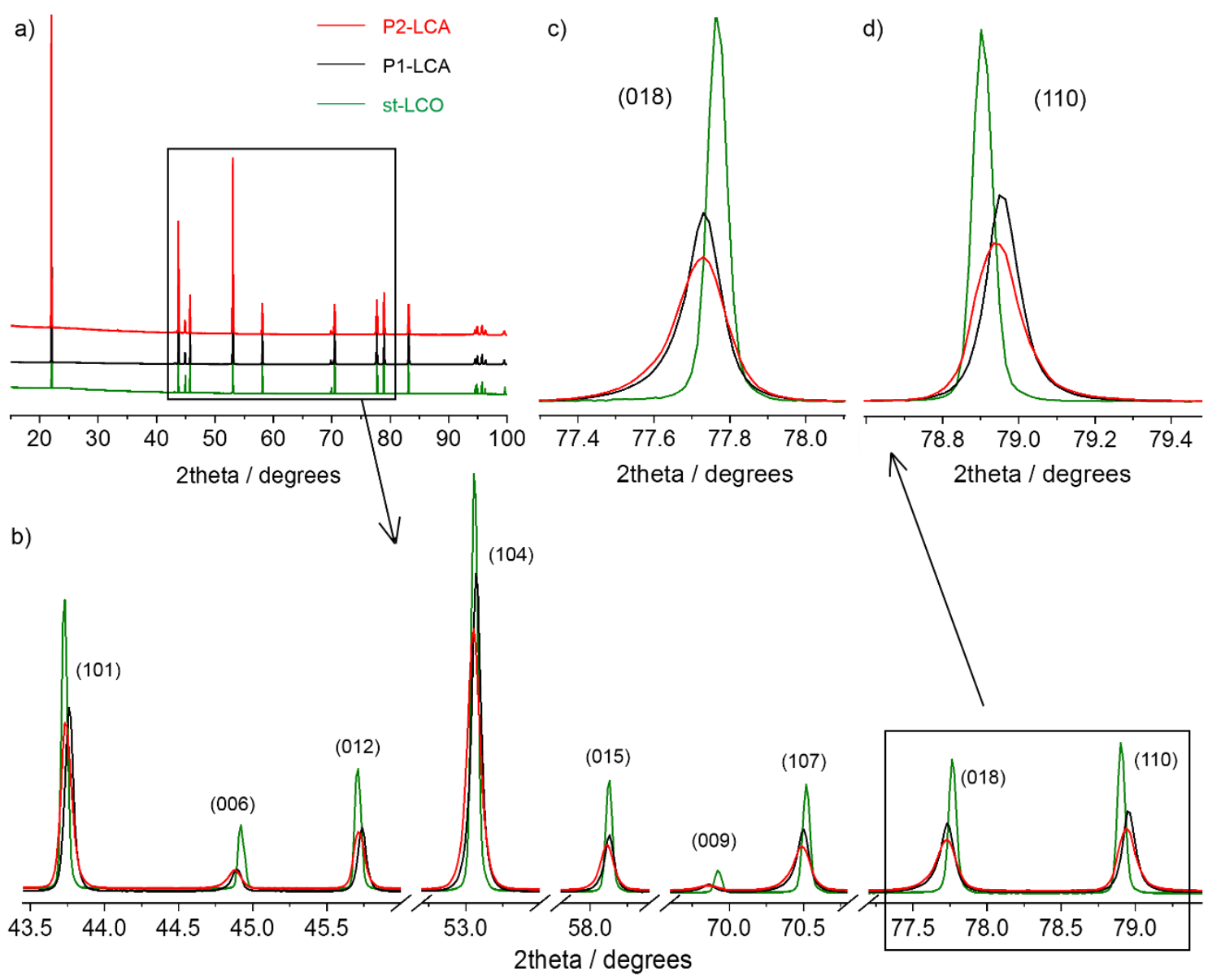

Figure 6. a) Synchrotron X-ray diffraction (SXRD) patterns obtained for P1 - and P2-LCA, as compared to undoped $\mathrm{LiCoO}_{2}$ (st-LCO). All patterns were collected for $\lambda=0.826 \AA$, but are converted here to $\lambda\left(\mathrm{Cока1}_{1}\right)=1.790 \AA$ for better comparison with all XRD patterns showed throughout the article. Zooms on several lines is shown in b) and a larger zoom in $\left(\begin{array}{lll}0 & 1 & 8\end{array}\right)$ and $\left(\begin{array}{lll}1 & 1 & 0\end{array}\right)$ peaks is provided in $\left.\mathbf{c}\right)$ and $\left.\mathbf{d}\right)$. 


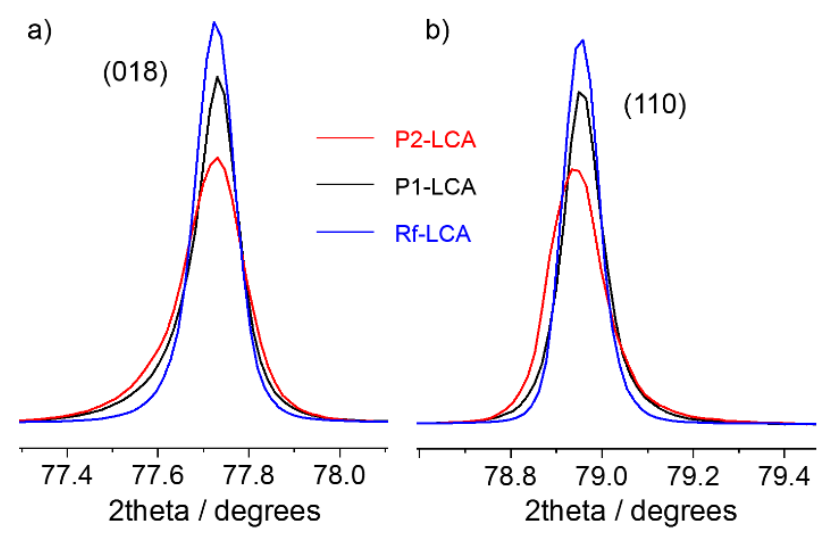

Figure 7. Zoom on the a) $\left(\begin{array}{lll}0 & 1 & 8\end{array}\right)$ and b) $\left(\begin{array}{lll}1 & 1 & 0\end{array}\right)$ SXRD peaks for P1- and P2-LCA normalized to the peak areas, as compared to the reference sample prepared from coprecipitation (Rf-LCA). 


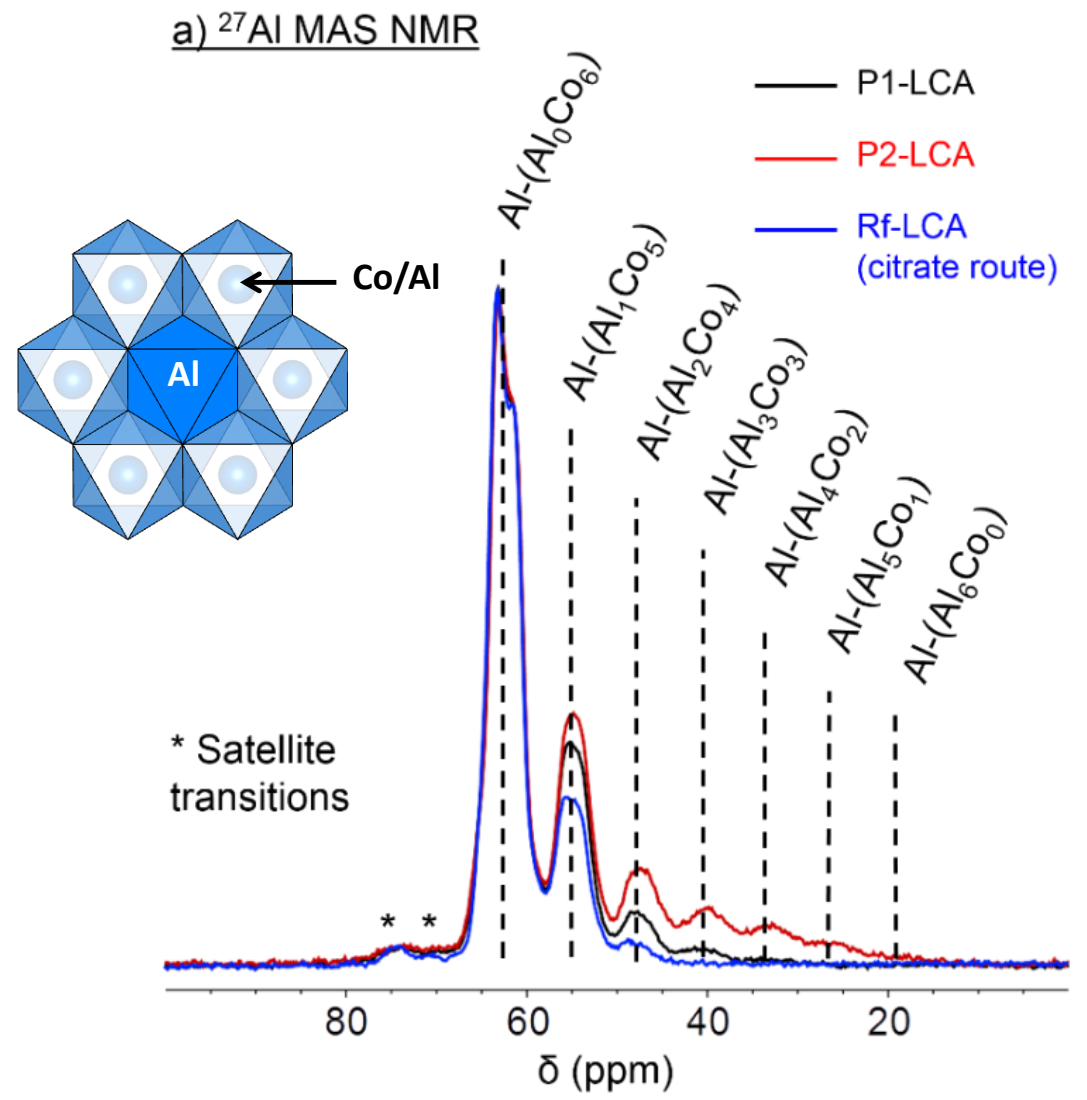

b)

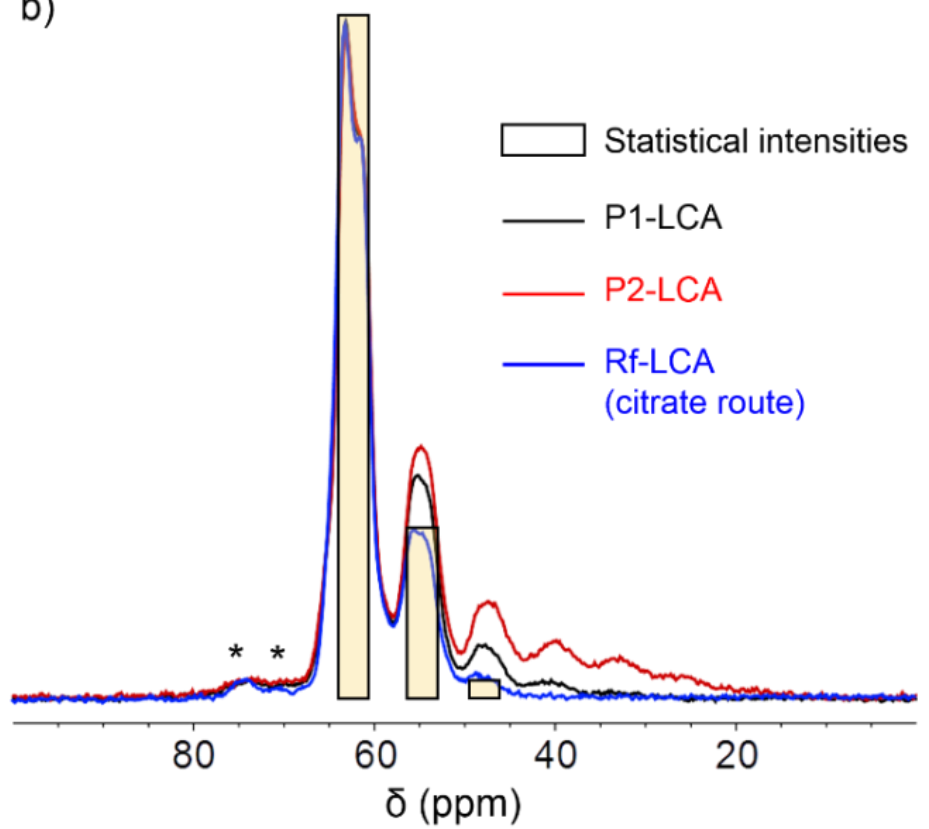

Figure 8. a) ${ }^{27} \mathrm{Al}$ MAS NMR spectra recorded at $130.33 \mathrm{MHz}$ using a $30 \mathrm{kHz}$ spinning frequency of the P1-LCA and P2-LCA samples compared with the one recorded for a 4\% Al doped LCA samples prepared by a citrate route used as reference and $\mathbf{b}$ ) comparison with the theoretical intensity distribution of the different Al environments versus Co, expected for a $4 \% \mathrm{Al}$-doped sample. 


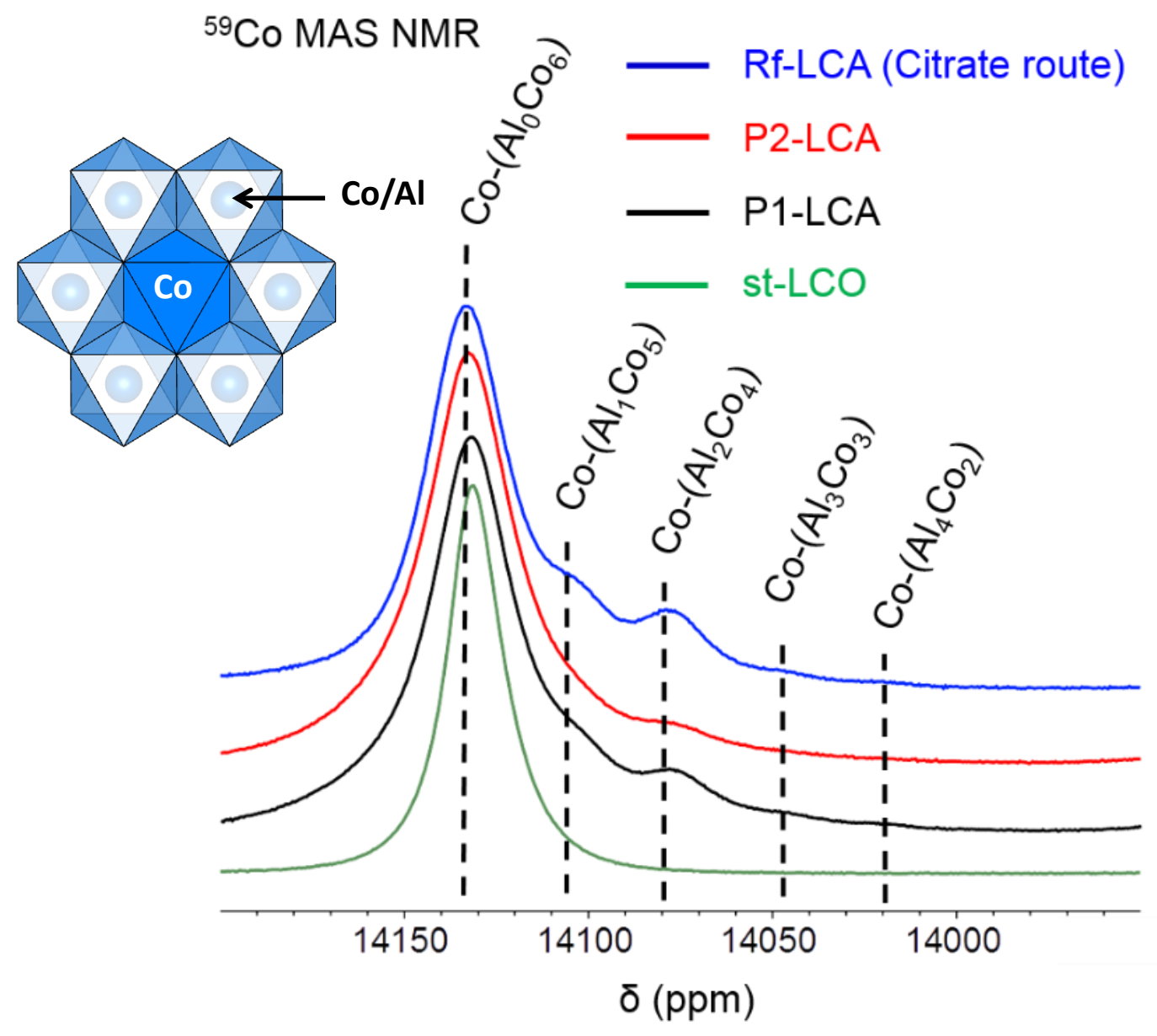

Figure 9. ${ }^{59} \mathrm{Co}$ MAS NMR spectra recorded at $120.35 \mathrm{MHz}$ using a $30 \mathrm{kHz}$ spinning frequency of the P1-LCA and P2-LCA samples compared with the ones recorded for undoped st-LCO and a 4\% Al doped LCA samples prepared by a citrate route used as references. 

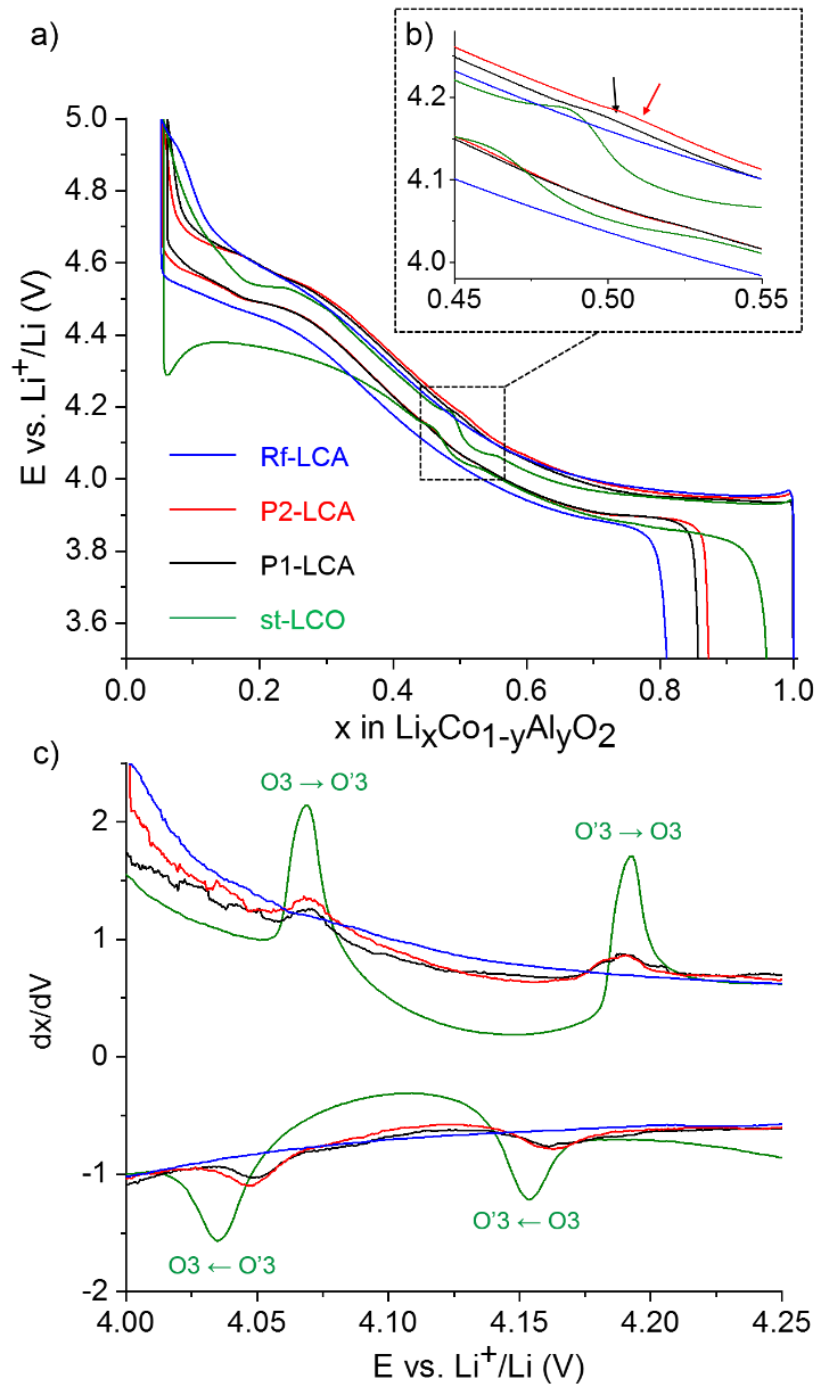

Figure 10. a) $1^{\text {st }}$ cycle for P1-LCA (in black) and P2-LCA (in red) at C/20 as positive electrode in Li//LCA cells, as compared to those of the reference LCA prepared from a coprecipitation route (Rf-LCA) and undoped LCO (st-LCO). A zoom corresponding to the $\mathrm{O} 3$ $\leftrightarrow$ O'3 transition is given in b). Associated dx/dV curves for $4.00-4.25 \mathrm{~V}$ window are plotted in c). 


\section{T.O.C}

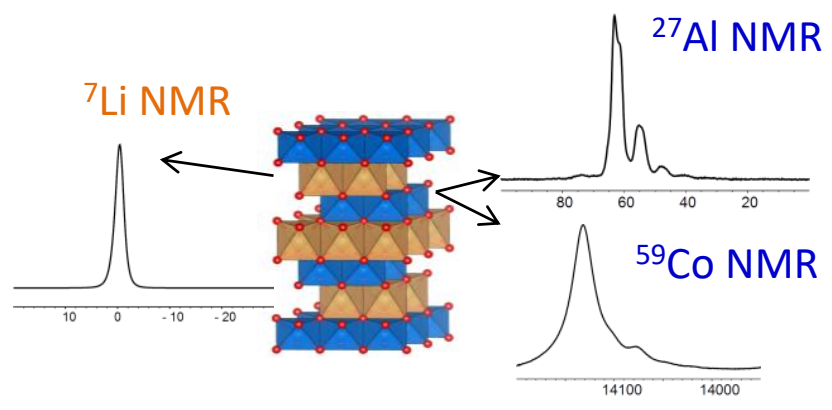

\section{Synopsis:}

Synchrotron XRD and ${ }^{7} \mathrm{Li},{ }^{27} \mathrm{Al}$ and ${ }^{59} \mathrm{Co}$ MAS NMR were used to probe, at different scales, the Li stoichiometry and $\mathrm{Al}$ homogeneity in $4 \% \mathrm{Al}$ doped $\mathrm{LiCoO}_{2}$ samples used as positive electrode for Li-ion batteries, prepared with various synthesis routes. 